University of Nebraska - Lincoln

DigitalCommons@University of Nebraska - Lincoln

2006

\title{
Phylogenetics of the Florally Diverse Andean Clade lochrominae (Solanaceae)
}

Stacey DeWitt Smith

University of Nebraska - Lincoln, ssmith19@unl.edu

David A. Baum

University of Wisconsin - Madison

Follow this and additional works at: https://digitalcommons.unl.edu/bioscifacpub

Part of the Life Sciences Commons

Smith, Stacey DeWitt and Baum, David A., "Phylogenetics of the Florally Diverse Andean Clade lochrominae (Solanaceae)" (2006). Faculty Publications in the Biological Sciences. 109.

https://digitalcommons.unl.edu/bioscifacpub/109

This Article is brought to you for free and open access by the Papers in the Biological Sciences at DigitalCommons@University of Nebraska - Lincoln. It has been accepted for inclusion in Faculty Publications in the Biological Sciences by an authorized administrator of DigitalCommons@University of Nebraska - Lincoln. 


\title{
Phylogenetics of the florally diverse Andean Clade IOCHROMINAE (SOLANACEAE) ${ }^{1}$
}

\author{
Stacey DeWitt Smith ${ }^{2,3}$ and David A. Baum ${ }^{2}$ \\ ${ }^{2}$ Department of Botany, University of Wisconsin, Madison, Wisconsin 53706 USA
}

\begin{abstract}
Recent molecular phylogenetic studies of Solanaceae have identified many well-supported clades within the family and have permitted the creation of a phylogenetic system of classification. Here we estimate the phylogeny for Iochrominae, a clade of Physaleae sensu Olmstead et al. (1999), which contains 34 Andean species encompassing an immense diversity of floral forms and colors. Using three nuclear regions, ITS, the second intron of $L E A F Y$, and exons 2 to 9 of the granule-bound starch synthase gene (waxy), we evaluated the monophyly of the traditional genera comprising Iochrominae and assessed the extent of interspecific hybridization within the clade. Only one of the six traditionally recognized genera of Iochrominae was supported as monophyletic. Further, comparison of the individual nuclear data sets revealed two interspecific hybrid taxa and a third possible case. These hybrid taxa occur in the Amotape-Huancabamba zone, a region between the northern and central Andes that has the greatest diversity of Iochroma species and offers frequent opportunities for hybridization in areas of sympatry. We postulate that periodic hybridization events in this area coupled with pollinator-mediated selection and the potential for microallopatry may have acted together to promote diversification in montane Andean taxa, such as Iochrominae.
\end{abstract}

Key words: floral evolution; granule-bound starch synthase; interspecific hybridization; $L E A F Y$; phylogeny; pollination; reticulate evolution; speciation.

The tropical Andes comprise the pre-eminent hotspot of plant biodiversity, with approximately $15 \%$ of all plant species native to that region (Myers et al., 2000). Many plant families, though cosmopolitan, have centers of diversity in western South America, for example, Ericaceae, Orchidaceae, and Solanaceae (Dressler, 1981; D’Arcy, 1991; Luteyn, 2002). An important contributor to the origin of this diversity is the topological and environmental variation resulting from the uplift of the Andes (Gentry, 1982; Hooghiemstra et al., 2002). Phylogenetic studies support an association between the diversification of Andean plants (von Hagen and Kadereit, 2003; Kay et al., 2005) and animals (Patton and Smith, 1992; Bates and Zink, 1994; Brower, 1994) and the major episodes of Andean uplift, beginning in the early Miocene (ca. 20 mya) and ending in the Pliocene (ca. 3 mya) (Hoorn et al., 1995; Hooghiemstra and van der Hammen, 1998). Indeed, the parallel invasions of higher elevations by numerous plant groups and the coincident radiations of pollinating animals,

\footnotetext{
${ }^{1}$ Manuscript received 7 December 2005; revision accepted 1 May 2006.

The authors thank S. Hall, O. Jadan, D. Neill, C. Padilla, W. Quizhpe, A. Rodriguez, H. Vargas, V. Zak and in particular, S. Leiva G., for assistance during fieldwork and plant collection; N. W. Sawyer for determinations of Cuatresia and Larnax; M. Nee for determinations of Lycianthes and Capsicum; S. Keel for determination of Salpichroa; D. G. Howarth for advice with $L F Y$; R. G. Olmstead for providing DNA of Leucophysalis grandiflora and Tubocapsicum anomalum; L. Bohs for material of Dunalia brachyacantha, Saracha punctata, and Acnistus arborescens; G. van der Weerden for material of E. lorentzii; A. Tye for help in obtaining samples of I. ellipticum; P. E. Berry, L. Bohs, J. W. Boughman, N. I. Cacho, M. Nee, R. G. Olmstead, D. M. Spooner, K. J. Sytsma, and T. J. Theim for helpful discussion; two anonymous reviewers for useful comments; B. Larget for advice regarding Bayesian analyses; $\mathrm{K}$. Elliot for assistance with illustrations; and R. A. Smith for editing. Finally, the authors acknowledge financial support from the National Science Foundation grant DEB-0309310, the University of Wisconsin chapter of Graduate Women in Science, the Marie Christine Kohler Fellowship, the American Society of Plant Taxonomists, the University of Wisconsin Tinker-Nave Fund, and the O. N. Allen Memorial Fund.

${ }^{3}$ Author for correspondence (e-mail: sdsmith4@wisc.edu)
}

e.g., hummingbirds (Bleiweiss, 1998), may explain the "explosive" speciation seen in some Andean groups (Gentry, 1982; Luteyn, 2002). Here we investigate the phylogenetic history of Iochrominae, a group of Andean Solanaceae, which have radiated in floral morphology and pollination system (Cocucci, 1999) and which may serve as a model system for other Andean radiations.

Recent phylogenetic analyses using plastid genes have greatly clarified relationships within Solanaceae and allowed for the creation of a phylogenetic system of classification (Olmstead and Sweere, 1994; Olmstead et al., 1999; Martins and Barkman, 2005; Olmstead et al., University of Washington, personal communication). Iochrominae sensu Olmstead et al. (1999) is a clade of Physaleae comprising around 34 mainly Andean species traditionally assigned to six genera: Acnistus Schott, Dunalia H.B.K, Eriolarynx (Hunz.) Hunz., Iochroma Benth., Saracha R. and P., and Vassobia Rusby (Table 1). In the Olmstead et al. (1999; R. G. Olmstead, University of Washington, unpublished manuscript) scheme, Iochrominae together with Physalinae and Withaninae form the large clade Physaleae, which is sister to Capsiceae. Although the phylogenetic classification was not accompanied by a morphological reassessment, Iochrominae can be distinguished from other subtribes in Physaleae by the fact that they are all woody shrubs or small trees and often have showy tubular flowers. In a recent morphological phylogenetic analysis (Sawyer, 2005), all Iochrominae genera except one, Acnistus, were found to be monophyletic, united most notably by the rounded-mucronate shape of the fruiting calyx margin and the presence of sclerosomes in the fruit wall.

Although it contains only one-third the number of species in its probable sister group Physalinae, Iochrominae boasts a greater floral diversity, spanning all major flower colors and forms found in the entire Solanaceae. Iochrominae flowers may be red, orange, yellow, green, blue, purple, or white, and the corolla varies from rotate to tubular, with over eight-fold variation in tube length across species (Shaw, 1998; Hunziker, 2001; Table 1). In contrast, a vast majority of taxa within 
TABLE 1. Summary information for genera of Iochrominae. Number of species is from recent treatments and descriptions (Acnistus [Hunziker, 1982], Eriolarynx [Hunziker, 2000, 2001], Dunalia [Hunziker, 1960, 2001], Iochroma [Leiva, 1995; Leiva et al., 1998, 2003; Shaw, 1998], Saracha [Alvarez, 1996], Vassobia [Hunziker, 1984, 2001]).

\begin{tabular}{|c|c|c|c|c|c|}
\hline Genus & No. species & No. sampled & Distribution & Elevation (m a.s.l.) & Distinctive features \\
\hline Acnistus & 1 & 1 & $\begin{array}{l}\text { Southern Mexico, Central America, the } \\
\text { Caribbean, northern South America } \\
\text { and eastern Brazil }\end{array}$ & $300-2000$ & $\begin{array}{l}\text { Campanulate or funnel-shaped fragrant flowers; } \\
\text { valvate bud aestivation; triangular corolla lobes; } \\
\text { green markings inside corolla lobes; edible fruit }\end{array}$ \\
\hline Dunalia & 5 & 5 & Colombia to Argentina & $1600-3700$ & $\begin{array}{l}\text { Often spiny; a few dioecious or gynodioecious; } \\
\text { tubular flowers with wing-like appendages of stapet } \\
\text { (filament base) }\end{array}$ \\
\hline Eriolarynx & 3 & 2 & Bolivia and Argentina & $1000-3000$ & $\begin{array}{l}\text { Rotate or campanulate flowers with a dense ring } \\
\text { of trichomes at base of corolla tube; stapet with } \\
\text { small projections ("auricles") }\end{array}$ \\
\hline Iochroma & $\begin{array}{c}21+3 \\
\text { undescribed taxa }\end{array}$ & $\begin{array}{c}21+3 \\
\text { undescribed taxa }\end{array}$ & $\begin{array}{l}\text { Colombia to Peru, with one species } \\
\text { in the Galapagos* }\end{array}$ & $1100-3500$ & $\begin{array}{l}\text { Tubular, often colorful flowers, with inflated calyces in } \\
\text { some species }\end{array}$ \\
\hline Saracha & 2 & 2 & Venezuela to Bolivia & $2700-4500$ & $\begin{array}{l}\text { Occasionally spiny; coriaceous to subcoriaceous leaves; } \\
\text { campanulate or funnel-shaped flowers; pyrenes in fruit }\end{array}$ \\
\hline Vassobia & 2 & 2 & $\begin{array}{l}\text { Bolivia, Argentina, Paraguay, } \\
\text { Uruguay and Brazil }\end{array}$ & $300-2700$ & $\begin{array}{l}\text { One spiny; campanulate flowers mostly glabrous; } \\
\text { stapet with auricles }\end{array}$ \\
\hline
\end{tabular}

Note: *The range for Iochroma excludes the two southern Andean species shown in this study not to belong in Iochroma.

Physalinae, Withaninae, and Capsiceae have small, white or yellow, rotate flowers, and there are no instances of long, tubular, red or purple corollas in these three clades. Thus, the brightly colored tubular flowers likely represent a derived feature that arose within or at the base of Iochrominae.

The great floral diversity of Iochrominae sensu Olmstead et al. (1999) has misled classifications based on morphology. For example, Hunziker's (2001) morphologically delimited Iochrominae included Oryctes S. Watson, a monotypic tubularflowered genus native to California and Nevada. Oryctes has since been shown to be nested within Physalinae, probably sister to Leucophysalis (Whitson and Manos, 2005; Olmstead et al., University of Washington, personal communication). Similarly, Sawyer's (2005) morphological cladistic analysis of Physaleae identified an Iochrominae clade that included all genera except Acnistus, which appeared with Tubocapsicum in a distant clade. Although Acnistus and the monotypic Japanese Tubocapsicum share small campanulate-infundibuliform flowers with valvate bud aestivation, molecular studies strongly suggest that Tubocapsicum is more closely related to other Physaleae (e.g., Nothocestrum and Withania) than to Acnistus and other Iochrominae (Olmstead et al., 1999; Olmstead et al., University of Washington, personal communication).

Another challenge in the systematics of Iochrominae is the potential for hybridization among species and across generic boundaries. Horticulturists have generated several hybrids (e.g., I. australe $\times$ I. cyaneum), and botanists have occasionally encountered hybrid populations in nature (Shaw, 1998; S. D. Smith, personal observation). The ease of crossing, the overlapping species ranges of many Iochrominae, and the observation of natural hybrids suggest that hybridization may have been important in the evolutionary history of Iochrominae. Combined with external sources of information such as morphology, biogeography, and cytology, phylogenetic estimation using multiple genetic markers can help identify instances of hybridization.

In this study, we used three nuclear regions, the internal transcribed spacer (ITS), exons 2 through 9 of the nuclear granule-bound starch synthase gene (GBSSI or waxy), and the second intron of LEAFY ( $L F Y$ ) to estimate the phylogeny of Iochrominae. Both ITS and waxy have been useful in clarifying specific and generic relationships in Solanaceae (e.g., Marshall et al., 2001; Peralta and Spooner, 2001; Whitson and Manos, 2005). $L F Y$ introns are increasingly utilized for resolving interspecific relationships and identifying hybrid taxa (e.g., Oh and Potter, 2003; Howarth and Baum, 2005), although this is the first study to use $L F Y$ in Solanaceae systematics. Our specific objectives were to evaluate the monophyly of the six traditional genera of Iochrominae and to assess the extent of interspecific hybridization. We close by considering our results in a biogeographical context.

\section{MATERIALS AND METHODS}

Taxon sampling - This study includes a nearly complete sampling of Iochrominae (Table 1) and a broad sampling of related lineages in the Solanoid radiation. Thirty-three of the 34 commonly recognized species of Iochrominae (all but Eriolarnyx iochromoides) were sampled in this study, as well as three as yet undescribed taxa (Appendix 1). The status of these unnamed taxa is under review by S. Leiva G., and for the purposes of this study, we will use temporary names, indicated by quote marks, based on their likely species epithets (S. Leiva G., Herbario Antenor Orrego, personal communication). For Iochroma peruvianum, a species known only from the type collection, our determination remains tentative because we were unable to find the species in its type locality and have here sampled individuals from another locality that closely resemble the type but have some small differences. For one ingroup species, A. arborescens, multiple individuals were included because the species is extremely widespread and variable.

Three ingroup taxa were suspected to have recent hybrid ancestry: Iochroma "sagasteguii," I. ayabacense, and I. stenanthum. These species are endemic to northern Peru and are often found in sympatry with other species of Iochroma and Acnistus. They share some characteristics of Iochroma (e.g., tubular flowers, purple coloration in the latter two) and some of Acnistus (e.g., yellowgreen markings inside the corolla lobes), making their taxonomic affinity unclear. Preliminary chromosome counts for one of these three species, I. ayabacense suggest that it is $n=12$ (S. D. Smith and V. Kolberg, University of Wisconsin, unpublished data) as are other species and genera of Iochrominae (Hunziker, 2001, and references therein). We, therefore, considered these taxa to be possible homoploid hybrids.

The 10 outgroup taxa were selected by reference to the plastid phylogeny of Solanaceae (Olmstead et al., 1999) and included Nicandreae (Nicandra), Solaneae (Solanum), Capsiceae (Capsicum and Lycianthes) and other members of Physaleae (Leucophysalis, Physalis, Salpichroa, Tubocapsium, and Witheringia) (Appendix 1). Also, included were the Andean genera Cuatresia and Larnax, which have not yet been incorporated into the phylogenetic 
classification scheme for the family, but appear to belong in Physaleae (R. G. Olmstead et al., University of Washington, unpublished manuscript).

Data collection-Total genomic DNA was extracted from silica-dried leaf material (Chase and Hills, 1991) using a modified $2 \times$ CTAB protocol (Doyle and Doyle, 1987). ITS was amplified as described in Baum et al. (1998) with primers ITS leu.1 (Andreasen et al., 1999) and ITS4 (White et al., 1990) and sequenced with these two primers plus ITS2 (White et al., 1990) and ITS3B (Baum et al., 1994).

The waxy region was amplified using primers $5^{\prime}$ and $3^{\prime}$ and sequenced using primers GBSSI-A, $-\mathrm{B},-\mathrm{C}_{\mathrm{R}}$, and $-\mathrm{D}_{\mathrm{R}}$ designed by Peralta and Spooner (2001). For difficult taxa, four Iochrominae specific primers were designed: F41, F420, R991, and R1235 (Appendix 2). Each $25 \mu \mathrm{L}$ waxy PCR reaction contained $2.5 \mu \mathrm{L} 10 \times$ PCR Buffer (Qiagen, Valencia, California, USA), $2.5 \mu \mathrm{L}$ of $25 \mathrm{mM} \mathrm{MgCl} 2,1.0 \mu \mathrm{L}$ of $10 \mathrm{mM}$ dNTPs, $1.0 \mu \mathrm{L}$ of each primer $(10 \mu \mathrm{M}$ solutions), $0.125 \mu \mathrm{L} \mathrm{Taq}$ polymerase (5 units/ $\mu \mathrm{L}$ ), and approximately $100 \mathrm{ng}$ of template DNA. The PCR program was $95^{\circ} \mathrm{C}$ for $2 \mathrm{~min}$, then 35 cycles of $95^{\circ} \mathrm{C}$ for $45 \mathrm{~s}, 56^{\circ} \mathrm{C}$ for $30 \mathrm{~s}, 72^{\circ} \mathrm{C}$ for $3 \mathrm{~min}$, followed by a final extension of $72^{\circ} \mathrm{C}$ for $5 \mathrm{~min}$

The second intron of $L F Y$ was initially amplified and cloned from a subset of taxa using degenerate primers F2 and R1 (Howarth and Baum, 2005). These sequences were used to create Solanoid specific primers (LFYSOL-F7, -F68, -R700, -R1000 in Appendix 2). The PCR reactions for $L F Y$ differed from the waxy reactions in that they contained $2.0 \mu \mathrm{L} \mathrm{MgCl}_{2}$ and $1.0 \mu \mathrm{L}$ Q-solution (Qiagen). The PCR program for $L F Y$ amplification was $95^{\circ} \mathrm{C}$ for $4 \mathrm{~min}$, then 35 cycles of $95^{\circ} \mathrm{C}$ for $1 \mathrm{~min}, 48^{\circ} \mathrm{C}$ for $1 \mathrm{~min}, 72^{\circ} \mathrm{C}$ for $3 \mathrm{~min}$, followed by a final extension of $72^{\circ} \mathrm{C}$ for $5 \mathrm{~min}$. All PCR products were purified with AMPure using manufacturer's protocols (Agencourt Bioscience, Beverly, Massachusetts, USA).

Copy number and allelic variants are of concern when using nuclear genes for phylogenetics. The ITS region, as part of the repeating units of rDNA in the nuclear genome, undergoes concerted evolution, potentially homogenizing the many copies (Hamby and Zimmer, 1992). This may explain why direct sequencing was possible for ITS for all taxa. With the single or low copy nuclear loci, $L F Y$ and waxy, direct sequencing often failed to yield a single sequence. In these cases, PCR products were gel-purified with the QIAquick gel extraction kit (Qiagen) and cloned using the pGEM-T easy vector system (Promega, Madison, Wisconsin, USA) following the manufacturer's protocol Five to eight clones from each product were sequenced.

Sequencing used ABI sequencing reagents (Applied Biosystems, Foster City, California, USA). Each 10- $\mu \mathrm{L}$ cycle sequencing reaction contained $1.0 \mu \mathrm{L}$ of purified PCR product, $2 \mu \mathrm{pM}$ of primer, $2 \mu \mathrm{L}$ Big Dye, and $2 \mu \mathrm{L}$ of sequencing buffer and was cycled through a program of $94^{\circ} \mathrm{C}$ for $2 \mathrm{~min}$, then 30 cycles of $94^{\circ} \mathrm{C}$ for $20 \mathrm{~s}, 47^{\circ} \mathrm{C}$ for $20 \mathrm{~s}$, and $60^{\circ} \mathrm{C}$ for $3 \mathrm{~min}$. Reactions were cleaned using CleanSEQ (Agencourt) and run on ABI PRISM 3700 DNA analyzer at the University of Wisconsin Sequencing Facility. Sequences were edited in Sequencher (Gene Codes Corp., Ann Arbor, Michigan, USA) and aligned manually in MacClade 4.0 (Maddison and Maddison, 2000). Unique clones were maintained in the alignment until data collection was complete Minor allelic variants (five or fewer substitutions per kilobase) were combined to create a consensus sequence for the species with differences coded as ambiguities. When alleles from a single species differed markedly in sequence or in length (due to indels) but still formed a clade in phylogenetic analyses, the allele giving the shortest branch in a parsimony tree was kept for analysis. In cases where the two alleles of a given species did not consistently form as a clade, both were kept for analysis. We use the term "divergent alleles" for such sequences for the remainder of the paper.

Sequences were examined for evidence of intragenic recombination by visual examination of the spatial distribution of different site patterns. Additionally, the sequences were analyzed for evidence of recombination using the MaxChi (Maynard Smith, 1992) and GENECONV (Padidam et al., 1999) methods (with default settings) in the program RDP (Martin and Rybicki, 2000). These methods have a limited ability to detect recombination, but are still potentially informative (Posada and Crandall, 2001; Posada, 2002). Final sequence alignments were deposited in TreeBASE (study accession number S1498, http://www.treebase.org).

Phylogenetic reconstruction-For parsimony analyses, all characters were equally weighted, and gaps were treated as missing characters. Heuristic searches were conducted in PAUP*, version 4.0b10 (Swofford, 2002), using 1000 random taxon addition sequences (holding two trees at each step) with tree-bisection-reconnection (TBR) branch swapping and keeping up to 100 most parsimonious trees (MPTs) per random addition replicate. Similar to Catalán et al. (1997), we next completed a heuristic search using the same settings but with 5000 random taxon additions and retaining only trees not compatible with the strict consensus of the first parsimony search (by enforcing the strict consensus as a reverse constraint). If the second search returned only trees longer than first search, then we considered the MPTs from the first search an adequate sample of parsimony tree space. If we found shorter trees, we repeated the process until no additional MPTs were recovered. To estimate clade support, heuristic searches were completed for 1000 bootstrap replicates with 10 random sequence additions (holding one tree at each step), TBR branch swapping, and maxtrees set to 100 .

For likelihood analyses, the best fitting model was chosen by hierarchical likelihood ratio tests. Likelihood scores were calculated in PAUP* (Swofford, 2002) for the following models (in order of increasing complexity): JC, K2P, HKY, HKY $+\Gamma$, HKY $+\Gamma+\mathrm{I}$, GTR $+\Gamma$, and GTR $+\Gamma+\mathrm{I}$ (Swofford et al., 1996, and references therein). The most-parsimonious tree (MPT) with the highest likelihood under the JC model was used for calculating likelihoods under more complex models. Likelihood searches were carried out in PAUP* (Swofford, 2002) using the best fitting model with all the MPTs used as starting trees, TBR branch swapping, and model parameters estimated during the hierarchical likelihood ratio tests.

Bayesian analyses were performed with MrBayes, version 3.1.1 (Ronquist and Huelsenbeck, 2003). The ITS and $L F Y$ intron data sets were each treated as a single data partition, whereas the waxy data set was divided into three partitions: first and second codon positions, third codon positions, and introns. Thus, the combined data set had five total data partitions. Each partition was assigned the best fitting model as suggested by likelihood ratio tests using MPTs from each partition as described previously. Transition/transversion ratio, substitution rates, state frequencies, gamma shape parameters, and proportion of invariant sites were unlinked across partitions and estimated during the Markov Chain Monte Carlo (MCMC) runs. For the individual and combined data sets, we conducted four independent MCMC runs, each with two internal runs (nruns $=2$ ), to give eight tree files for each data set. Each run was initiated with a different starting seed and comprised four linked chains with temperature of 0.2 . The chains were run for 5000000 generations, sampling every 100 generations, except for ITS, for which we used 15000000 generations, sampling every 150 generations. Adequate mixing (sampling of tree and parameter space) was judged by movement among chains and acceptance rates, which should be between 10 and $70 \%$, and, most importantly, by convergence among independent runs with different starting points (Huelsenbeck et al., 2002). Inadequate mixing in some initial runs was corrected by adjusting the temperature and re-running the analysis. We considered that the runs had converged when the convergence diagnostics provided in sump output approached 1 and when clade credibilities (post burnin), branch lengths, and topologies were similar across the four independent runs. We discarded $10 \%$ of trees as our burn-in period, which appeared to be very conservative given visual inspection of likelihood-by-generation plots. Posterior probabilities (PP) were averaged across runs.

Statistical tests-We estimated the $g 1$ statistic, a measure of phylogenetic signal, for each data set in PAUP* using 10000 random trees. Significance of the statistic was assessed following Hillis and Huelsenbeck (1992).

Incongruence between the three data sets was estimated with the incongruence length difference (ILD) test (Farris et al., 1994), implemented as the partition homogeneity test in PAUP*. The test was conducted with 1000 replicate partitions, each subjected to heuristic parsimony searches, comprising 10 random taxon addition replicates with TBR branch swapping and keeping no more than 100 trees per random addition replicate. The difference in phylogenetic signal from the three data sets as manifested in differing tree topologies was further examined using Wilcoxon signed-ranks (WSR) tests, also known as Templeton tests (Templeton, 1983), implemented in PAUP*. A detailed description of the use of WSR tests to compare phylogenetic hypotheses is given in Larson (1994). Constrained searches completed in conjunction with WSR tests were carried out with the same settings as unconstrained parsimony searches (described previously).

We also examined incongruence between data sets in a Bayesian framework as described in Buckley et al. (2002). We determined whether the combined topology existed within the $95 \%$ credible set of trees from each gene. If not, we assumed that the gene in question evolved under a different topology or that the model of evolution was inappropriate. In these cases, we attempted to localize areas of discordance by comparing individual clade credibilities between the individual and combined analyses. 
TABLE 2. Summary statistics and analysis parameters for individual and combined data sets for phylogenetic analysis of Iochrominae. The number of most parsimonious trees includes only the unique trees after collapsing zero-length branches.

\begin{tabular}{|c|c|c|c|c|c|c|c|c|c|}
\hline Region & No. characters & $\begin{array}{l}\text { No. variable } \\
\text { characters }\end{array}$ & $\begin{array}{l}\text { No. parsimony } \\
\text { informative } \\
\text { characters }\end{array}$ & $\begin{array}{c}\mathrm{CI} / \mathrm{RI} \text { (excluding } \\
\text { uninformative characters) }\end{array}$ & $g 1$ & Tree length & $\begin{array}{c}\text { No. most } \\
\text { parsimonious trees }\end{array}$ & $\begin{array}{l}\text { Best-fitting } \\
\text { likelihood model }\end{array}$ & $\begin{array}{l}\text { Temperature used in } \\
\text { Bayesian analysis }\end{array}$ \\
\hline ITS & 803 & 239 & 138 & $0.42 / 0.54$ & $-0.35^{*}$ & 670 & 16353 & GTR $+\Gamma+\mathrm{I}$ & 0.07 \\
\hline$L F Y$ & 1806 & 764 & 322 & $0.63 / 0.78$ & $-1.49^{*}$ & 1230 & 458 & $\mathrm{HKY}+\Gamma$ & 0.2 \\
\hline Combined ITS and waxy & 2275 & 728 & 305 & $0.48 / 0.66$ & $-0.47 *$ & 1393 & 180 & $\mathrm{GTR}+\Gamma+\mathrm{I}^{\mathrm{a}}$ & 0.06 \\
\hline
\end{tabular}

Notes: $\mathrm{CI}=$ consistency index; $\mathrm{RI}=$ retention index. ${ }^{*}$, significant phylogenetic signal $(P<0.01)$ according to the $g 1$ statistic (Hillis and Huelsenbeck, 1992).

${ }^{\text {a }}$ For likelihood searches of combined data sets, we used the indicated model, but for Bayesian searches, we applied the best fitting model for each individual data set to its partition.

\section{RESULTS}

Phylogenetic analyses of individual data sets-ITSSequences were completed for all taxa (Appendix 1) and easily aligned to provide a matrix of 803 characters (described in Table 2). We found no evidence of intragenic recombination, either by visual inspection or by use of MaxChi and GENECONV methods in the program RDP $(P>0.05)$. Relative to $L F Y$ and waxy, ITS had low consistency and low phylogenetic signal (Table 2), resulting in many more MPTs. Our initial Bayesian analyses showed variation in clade credibilities across runs, but lengthening the runs to 15000000 generations (sampling every 150 generations) produced identical majority-rule consensus trees with less than 5\% difference in PP across independent runs for clades with over 50\% PP. Also, the convergence diagnostic was 1.0 for each run and acceptance rates were between 10 and $70 \%$, indicating good mixing. Despite thorough exploration of tree space, ITS provided little resolution at any level and showed only a few strongly supported clades, which appeared consistently in the MP, ML, and Bayesian analyses. At the broader level, ITS data suggested that the mostly closely related taxa to Iochrominae are other Physaleae (bootstrap support $[\mathrm{BS}] 59 \%, \mathrm{PP}=1.0$; Fig. 1), but it did not provide support for any specific Physaleae lineage being sister to Iochrominae. Iochrominae appeared monophyletic $(\mathrm{BS}=86 \%$, $\mathrm{PP}=1.0$; Fig. 1), excluding the spiny Bolivian endemic $I$. cardenasianum, which apparently is not a member of Iochroma. Within Iochrominae, ITS resolved only small clades, such as Vassobia ( $\mathrm{BS}=76 \%, \mathrm{PP}=1.0$; Fig. 2) and the $\mathrm{C}$ clade $(\mathrm{BS}=93 \%$, $\mathrm{PP}=1.0$, see Fig. 2 legend for explanation of clade names). One interesting feature of the ITS phylogeny was the placement of the U group, which appeared as a clade (BS $=52 \%$; not shown) sister to the rest of Iochrominae (BS $=33 \%$; not shown) in parsimony analyses or as a basal grade in likelihood and Bayesian analyses (Fig. 2).

waxy-Most taxa were directly sequenced for waxy and only a few (Lycianthes, Larnax, Iochroma parvifolium, I. fuchsioides, and the three putative hybrids) required cloning. In
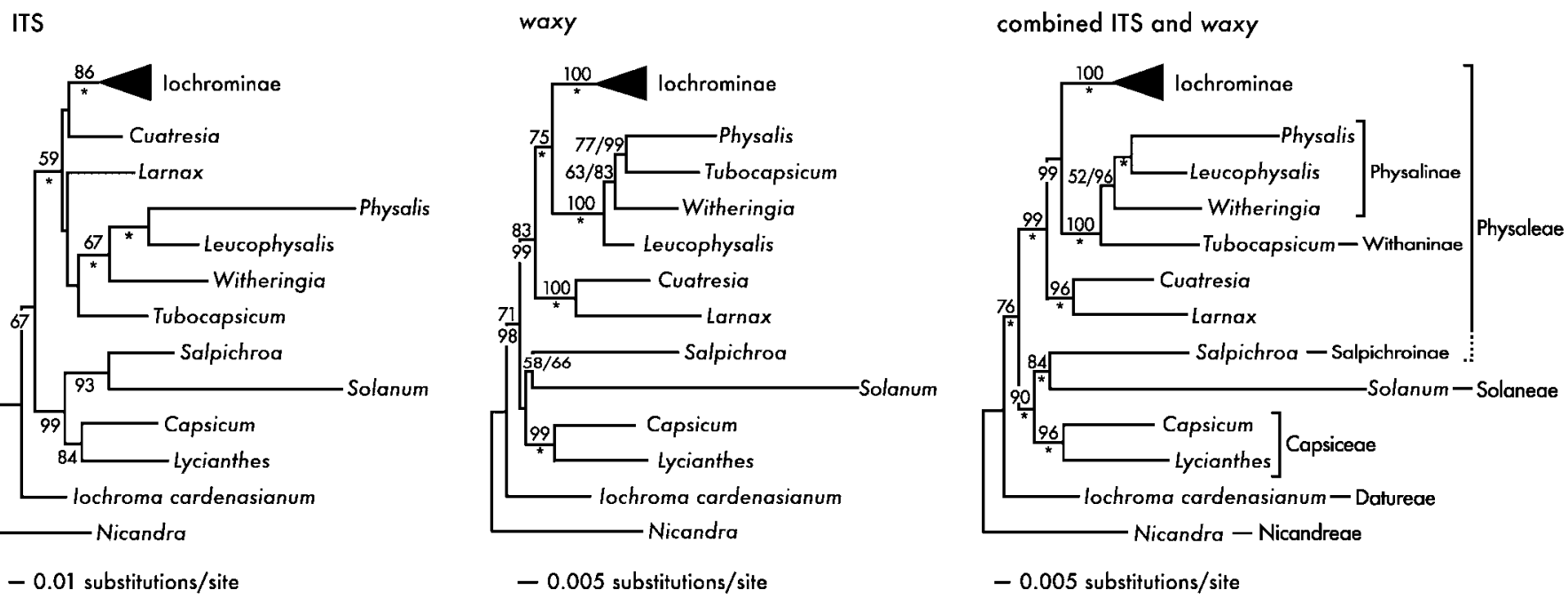

Revised Fig. 1. Maximum likelihood trees showing placement of Iochrominae within the Solanoideae. Regions analyzed are listed to the upper left of each tree. All trees are shown with branch lengths proportional to the estimated average number of substitutions per site under the models indicated in Table 2. Bootstrap support (BS) values $>50 \%$ are shown above branches or before the slash, and posterior probabilities (PP) $>0.75$ (shown as percentages) are below branches or after the slash. Asterisks indicate a PP of 1.0. The rightmost tree is labeled with Olmstead et al. (1999) tribal and subtribal groupings. Solid vertical lines label monophyletic groups; dashed vertical lines indicate non-monophyly. This figure differs from the print journal: the bootstrap value 90 with asterisk has been moved to the branch subtending the Salpichroa + Solanum + Capsicum + Lycianthes clade in the rightmost tree (combined ITS and waxy).

A formal erratum appears in the September issue. 

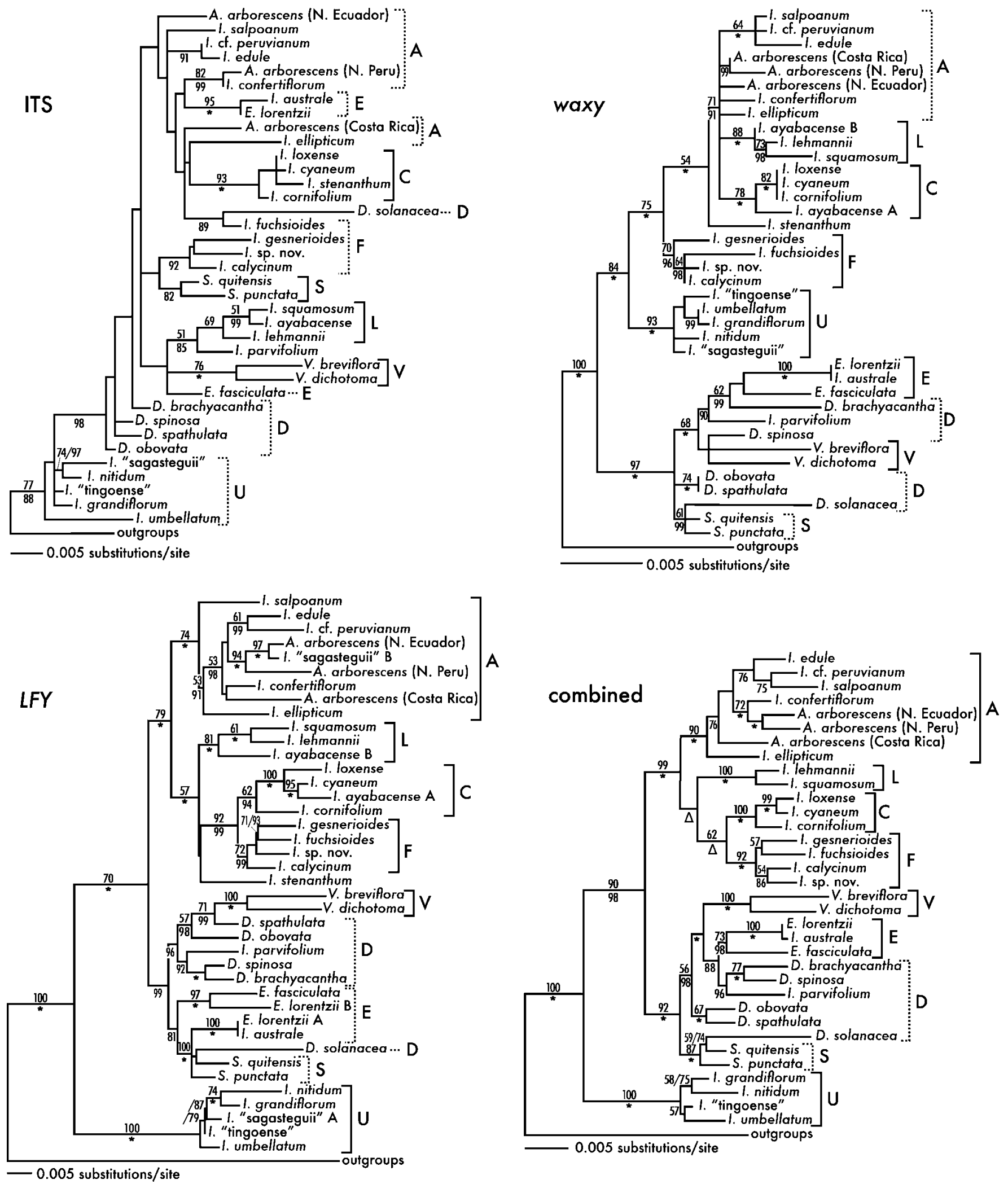

Fig. 2. Maximum likelihood trees of Iochrominae for individual and combined analyses. All trees are shown with branch lengths proportional to the estimated average number of substitutions per site under the models indicated in Table 2. Outgroups for ITS and waxy include all taxa shown in Fig. 1; outgroups for $L F Y$ and combined include only Physaleae (Physalis, Leucophysalis, Witheringia, Tubocapsicum, Cuatresia and Larnax; Fig 1.). Bootstrap support (BS) values $>50 \%$ are shown above branches or before the slash, and posterior probabilities (PP) $>0.75$ (shown as percentages) are placed below branches or after the slash. Asterisks indicate a PP of 1.0. To facilitate comparison of relationships among trees, groups of interest are labeled with vertical 
those cases, we conducted initial parsimony analyses to see if the separate clones formed a clade. When they did, we either created a consensus sequence (when clones differed by fewer than five bases per kilobase) or selected a single exemplar sequence. For I. ayabacense and I. "sagasteguii," two distinct sequence variants were found that did not form a clade. Both divergent alleles were retained in the final data set. We found no evidence of intragenic recombination among ingroup waxy sequences, either by visual inspection or by use of MaxChi and GENECONV methods in RDP $(P>0.05)$. Characteristics of the data set are given in Table 2 .

Bayesian analyses of the waxy data set mixed well as indicated by the convergence diagnostics and the low variation among independent runs. The waxy analyses strongly supported the monophyly of Iochrominae ( $\mathrm{BS}=100, \mathrm{PP}=1.0 ;$ Fig. 1$)$ and its inclusion in Physaleae ( $\mathrm{BS}=83, \mathrm{PP}=1.0$; Fig. 1$)$, perhaps as sister to Physalinae plus Tubocapsicum $(\mathrm{BS}=75, \mathrm{PP}=1.0$; Fig. 1). Like ITS, waxy showed I. cardenasianum to be distantly related from other iochromas. Further, all waxy analyses divided Iochrominae into a principally northern Andean clade containing Acnistus and Iochroma (A, C, L, F, and U clades; Fig. 2) and a mixed northern, central, and southern Andean clade containing members of Dunalia, Eriolarynx, Saracha, and Vassobia (D, E, S, and V; Fig. 2).

$L F Y$ - This region was more variable than waxy (Table 2), and could not be directly sequenced for many taxa. Nevertheless, most clones constituted minor sequence variants that were represented in the final matrix by consensus sequences. However, three of 49 taxa (Eriolarynx lorentzii, I. ayabacense, and $I$. "sagasteguii") contained two alleles that did not form a clade with others from the same accession. These divergent alleles were kept in the final matrix for phylogenetic analysis. We found no evidence of intragenic recombination in Iochrominae, either by visual inspection or with MaxChi and GENECONV methods implemented in RDP $(P>0.05)$.

Although $L F Y$ sequences were completed for all taxa, this intron could not be aligned outside Physaleae due to the enormous length variation $(2.2 \mathrm{~kb}$ in Capsiceae vs. $1.4 \mathrm{~kb}$ in Iochrominae). Characteristics of the final data set of 43 taxa are given in Table 2. Similar to waxy, final Bayesian analyses mixed well as judged by acceptance rates and agreement among runs. Although $L F Y$ was too variable to be informative outside of Physaleae, it provided a good resolution within Iochrominae. Using other Physaleae as outgroup taxa, as indicated by waxy and ITS (Fig. 1), LFY produced an ingroup topology with many of the same well-supported clades that appear in ITS and waxy, but with some differences in relationships among the groups. Unlike waxy but similar to ITS, $L F Y$ placed the $U$ clade sister to the rest of Iochrominae (BS 70\%, PP 1.0; Fig. 2). As in waxy analyses, $L F Y$ supported a northern Andean clade with Acnistus and most of Iochroma (A, C, L, and F; Fig. 2) and a clade with Dunalia, Eriolarynx, Saracha, and Vassobia (D, E, S, and V; Fig. 2). LFY supported a monophyletic group of Acnistus and Acnistus-like iochromas (the A clade, Fig. 2) sister to a clade comprising other Iochroma subclades (C, L, and F; Fig. 2). This is in contrast with waxy, which placed the $\mathrm{F}$ clade sister to a clade comprising A, L, and C (but with A unresolved).

Divergent alleles in LFY and waxy-Three species, Eriolarnyx lorentzii, Iochroma "sagasteguii," and I. ayabacense, had divergent $L F Y$ alleles, and I. ayabacense also had divergent waxy alleles. In the case of $E$. lorentzii, one $L F Y$ allele formed a clade with E. fasciculata and the other with I. australe (Fig. 2). When the two alleles are constrained to be sister, the resulting trees are significantly longer than the optimal trees (WSR, $P=0.0001-0.0017$ ), suggesting that $E$. lorentzii alleles are not exclusive and that there may be true genealogical discordance (e.g., due to lineage sorting or hybridization).

One $L F Y$ allele of Iochroma "sagasteguii" was sister to a sample of Acnistus arborescens, whereas the other fell in the distantly related $\mathrm{U}$ clade (Fig. 2). The $L F Y$ alleles of $I$. ayabacense were split between the $\mathrm{C}$ and $\mathrm{L}$ clades. When either I. "sagasteguii" or I. ayabacense alleles were forced to form a clade, the resulting trees were significantly longer than unconstrained trees (WSR, $P=0.0001-0.004$ for $I$. ayabacense and $P<0.0001$ for $I$. "sagasteguii"). Iochroma ayabacense also showed divergent waxy alleles, with one allele in the $\mathrm{C}$ clade and the other in the $\mathrm{L}$ clade, consistent with the $L F Y$ analysis (Fig. 2). Constraining the two waxy alleles from $I$. ayabacense to form a clade resulted in some significantly longer trees (WSR, $P=0.025-0.096$ ). The distant placement of I. "sagasteguii" $L F Y$ alleles and I. ayabacense $L F Y$ and waxy alleles points to a hybrid origin for these taxa, a possibility that will be explored in more detail in the discussion.

Discordance among genes-The ILD (Farris et al., 1994) was used as an initial test of "global" congruence among and within data partitions. An ILD test indicated that the assignments of characters to the three waxy partitions (first and second codon positions, third codon positions, and introns) was not significantly different from random $(P=0.70)$, suggesting that waxy can be treated as a single data partition. In contrast, pairwise comparisons of the ITS, $L F Y$, and waxy (excluding non-Physaleae outgroups and putative hybrids) all yielded significant ILD tests $(P<0.01)$, indicating that the three data sets are not drawn from the same population of characters (but see Darlu and Lecointre, 2002; Hipp et al., 2004). We attempted to localize the discordance by repeating the ILD test with successively pruned data sets (Table 3 ). We divided the data set into three parts, the ACLF group, the DESV group and the U group, and we found that only the DESV returned significant $P$-values (Table 3 ). However, simply deleting the DESV taxa from the larger clade did not result in insignificant ILD results (not shown), suggesting that it was not the sole source of incongruence.

Templeton tests-Although ILD tests suggested significant differences in signal among data sets, inspection of the

brackets on each tree. The labels D, E, S, and V indicate members of the traditional genera Dunalia, Eriolarynx, Saracha and Vassobia, respectively. Iochroma has been divided into smaller clades: A, including Acnistus and Acnistus-like iochromas; C, containing the type I. cyaneum; L, after I. lehmannii; $\mathrm{F}$, after I. fuchsioides; and U after I. umbellatum. Solid bracket lines indicate monophyly; dashed bracket lines indicate non-monophyly. The $\Delta$ 's in the combined tree designate points of difference between the combined likelihood tree and combined Bayesian consensus; PP for clade ACL is 0.97 and PP for clade AL is 1.0 (see text, Results, Combined analysis). 
TABLE 3. $P$ values from incongruence length difference (ILD) tests of combined data sets. In each case, the putative hybrids, Iochroma stenanthum, I. ayabacense, and I. "sagasteguii," were already removed.

\begin{tabular}{llll}
\hline \hline \multicolumn{1}{c}{ Data set } & ITS vs. waxy & ITS vs. $L F Y$ & LFY vs. waxy \\
\hline Iochrominae + Physaleae outgroups & $0.001^{* *}$ & $0.001^{* *}$ & $0.001^{* *}$ \\
Iochrominae & $0.001^{* *}$ & $0.002^{* *}$ & $0.007^{* *}$ \\
Clades A, C, L, F only & 0.446 & $0.057^{*}$ & 0.479 \\
Clades D, E, S, V only & 0.206 & $0.01^{* *}$ & $0.001^{* *}$ \\
Clade U only & 1.0 & 1.0 & 1.0 \\
\hline
\end{tabular}

Notes: Clade names (A, C, etc.) are explained in caption for Fig. 2. **, significant at $P<0.01 ; *$, marginally significant values.

individual trees revealed only eight points of hard incongruence (conflicting clades with $\mathrm{BS}>70$; Mason-Gamer and Kellogg, 1996) among the three gene trees (Fig. 2). Three of these cases were due to differences in the placement of divergent $L F Y$ or waxy alleles. We used Templeton tests to compare the remaining five sources of hard incongruence (Table 4). In all cases, one or the other partition failed to reject the conflicting resolution at the $P<0.05$ level. This suggests that the incongruence detected by ILD tests is "diffuse" rather than due to particular points of discordance.

Combined analysis-Before conducting combined analyses, we removed all of the putative hybrids, Iochroma stenanthum, I. ayabacense, and I. "sagasteguii," as they appeared to be a source of conflict among data sets. We chose not to remove $E$. lorentzii despite its divergent alleles because that would severely reduce our sampling of Eriolarynx. Instead, we removed the $E$. lorentzii $L F Y$ allele $\mathrm{B}$, whose position conflicts with that supported by ITS and waxy. In addition, we reduced the outgroup sampling to include only other Physaleae (Physalis, Leucophysalis, Witheringia, Tubocapsicum, Cuatresia, and Larnax; Fig. 1).

Parsimony analysis of the combined data set of 40 taxa and 4023 characters yielded 12 MPTs (Table 2) and increased support for many of the clades observed in individual data sets (Fig. 2). Similar results were obtained for ML and Bayesian analyses. For example, among individual analyses, the A clade only appeared in the $L F Y$ tree $(\mathrm{BS}=74 \%$; $\mathrm{PP}=1.0$; Fig. 2$)$, but it appeared in the combined analysis with a BS of $90 \%$ and $\mathrm{PP}$ of 1.0. Likewise, the placement of the $U$ clade sister to the rest occurred with moderate support in $L F Y(B S=70 \%, P P=1.0$; Fig. 2) and weak support in analyses of ITS (BS $=33 \%, \mathrm{PP}=$ 0.12 ; not shown), but appeared strongly supported in the combined analysis $(\mathrm{BS}=90 \%, \mathrm{PP}=0.99$; Fig. 2). Nonetheless several areas on the combined tree remain unresolved, most notably within the DESV clade and within the A clade. Also, there were differences among modes of analysis. Clades C, L, and $\mathrm{F}$ together formed a clade in parsimony and ML searches of the combined data (Fig. 2), but Bayesian analyses showed clade $\mathrm{F}$ as sister to an $\mathrm{A}, \mathrm{C}$, and $\mathrm{L}$ clade and clade $\mathrm{A}$ sister to clade $\mathrm{L}$ with high posterior probability $(\mathrm{PP}=0.96-1.0)$ at all relevant nodes (tree not shown, but see Fig. 2 caption). Exploration of pruned data sets (not shown) established that the resolution among the $\mathrm{A}, \mathrm{C}, \mathrm{L}$, and $\mathrm{F}$ clades in a Bayesian framework is very sensitive to the inclusion or exclusion of $\mathrm{L}$ and to model choice (e.g., whether data partitions were allowed to evolve under different models or whether they were linked as in traditional likelihood searches).
Congruence in a Bayesian framework-As an additional assessment of congruence, we compared the results of the Bayesian analysis of the combined data set (described previously) with the results from Bayesian analyses of individual data sets that had been pruned to the same 40 taxa (Buckley et al., 2002). The results of these runs are provided in Appendix S1 (see Supplemental Data accompanying the online version of this article). We found that there were no trees that were shared between the posterior distributions (post burn-in) of the individual and combined data sets. This is perhaps not surprising given that there are $1.3 \times 10^{55}$ possible unrooted trees for 40 taxa and thus a fairly small chance that different data sets would sample exactly equivalent topologies.

We next examined localized points of disagreement among data sets in the Bayesian framework. Within the ACLF group, we observed that $L F Y$ had a PP of 0.0 for F sister to ACL, whereas waxy had a PP of 0.0 for the F sister to $\mathrm{C}$ topology. This suggests that there may be true genealogical discordance between LFY and waxy within the ACLF clade (Table 4, conflict 5). A contrasting result was found with respect to the placement of the $\mathrm{U}$ clade (sister to the rest in $L F Y$ and sister to $\mathrm{A}, \mathrm{C}, \mathrm{L}$, and $\mathrm{F}$ in waxy). We found that trees with $\mathrm{U}$ sister to the rest of Iochrominae (the "U-sister" topology), as suggested by $L F Y$, appeared in waxy posterior distributions with a PP of 0.0078. Similarly U was sister to A, C, L, and F (the "U-nested" topology) in the $L F Y$ posterior with a PP of 0.001 . While these values are lower than the traditional 0.05 threshold, the fact that both topologies were present in the posterior distributions for both data sets suggests that there may not be hard incongruence (consistent with the WSR tests, Table 4). On the other hand, the fact that the combined analysis supports the U-sister topology more strongly than does $L F Y$ alone, suggests that $\mathrm{U}$-sister is a more plausible hypothesis at this time than U-nested.

\section{DISCUSSION}

Position of Iochrominae in Solanaceae-Our goal in outgroup sampling was to confirm the monophyly of Iochrominae and verify that it belongs in Physaleae as indicated by plastid data. Indeed, once Iochroma cardenasianum is excluded, Iochrominae appears to be monophyletic. Plastid data (Olmstead et al., University of Washington, personal communication) confirm the distant relationship of I. cardenasianum to Iochrominae and place it within the Datureae.

Our data support the inference that Iochrominae is part of Physaleae, but its relationship to other taxa remains unclear. Of the three markers, the $L F Y$ intron could not be readily aligned with the more distant outgroups, and ITS provided little resolution among Physaleae (Fig. 1). However, analysis of waxy alone and combined analysis of waxy and ITS strongly supported Iochrominae as sister to Physalinae sensu Olmstead et al. (1999) plus Tubocapsicum. This result disagrees with the most recent plastid phylogeny, which places Deprea plus Larnax sister to Iochrominae, albeit with weak support (Olmstead et al., University of Washington, personal communication). Resolving the lineages that comprise Physaleae and the relationships among them will require increased sampling and perhaps additional markers.

Taxonomic implications for genera of IochrominaeAcnistus-In Hunziker's (1982) revision of Acnistus, he acknowledged that Acnistus has greatest affinity to the genus 
TABLE 4. Wilcoxon signed-ranks tests of conflicting phylogenetic hypotheses. The instances of conflict described can be observed in the gene trees in Fig. 2. See Fig. 2 legend for explanation of clade names.

\begin{tabular}{|c|c|c|}
\hline Conflicting topologies & Constraint & Result \\
\hline $\begin{array}{l}\text { 2. A. arborescens (Peru) sister to I. confertiflorum (ITS: BS 82\%) } \\
\text { vs. sister to A. arborescens (Ecuador) (LFY: BS 94\%) }\end{array}$ & $\begin{array}{l}\text { Force } A \text {. arborescens (Peru) sister to } \\
\text { A. arborescens (Ecuador) in ITS } \\
\text { Force } I \text {. confertiflorum sister to A. arborescens } \\
\text { (Peru) in } L F Y\end{array}$ & $\begin{array}{l}\text { ITS: } P=0.68-0.87 \\
L F Y: P=0.16-0.51\end{array}$ \\
\hline $\begin{array}{l}\text { 5. C forms a clade with F (LFY: BS 92\%) } \\
\text { vs. with A and L (waxy: BS } 71 \% \text { ) }\end{array}$ & $\begin{array}{l}\text { Force } \mathrm{A}, \mathrm{L} \text {, and } \mathrm{C} \text { (including } I \text {. ayabacense) } \\
\text { to form a clade in } L F Y \\
\text { Force } \mathrm{C} \text { (including } I . \text { ayabacense } \mathrm{A} \text { ) and } \\
\text { clade } \mathrm{F} \text { to form a clade in waxy }\end{array}$ & $\begin{array}{l}L F Y: P=0.03-0.13 \\
\text { waxy: } P=0.05-0.16\end{array}$ \\
\hline
\end{tabular}

Iochroma. The important differences he noted between them were the small flowers and anthers of Acnistus, the calyx (accresent in Iochroma but not in Acnistus), and the bud aestivation (induplicate in Iochroma and valvate in Acnistus). Confusing this demarcation are a few species currently placed in Iochroma that have the latter two characteristics of Acnistus. For example, I. ellipticum and I. confertiflorum, two large-flowered species that were transferred from Acnistus by Hunziker (1977, 1982), have valvate bud aestivation and lack a strongly accresent calyx. This combination of traits is also found in two recently named species, $I$. edule and I. salpoanum (Leiva, 1995; Leiva et al., 2003) and in I. peruvianum. Furthermore, field observations of these five iochromas (S. D. Smith, personal observation) indicate that they share with Acnistus a conspicuous green mark on the inner surface of the corolla lobe, which fades to yellow as the flower ages (Fig. 3). Thus, it is not surprising that Acnistus and these five other species form a well-supported clade in our analyses (clade A), but whether this group should be officially segregated from Iochroma deserves careful consideration and will be discussed further (see Iochroma).

The small-flowered form traditionally named Acnistus arborescens occurs from Argentina to Mexico and the Caribbean and is morphologically variable, with 28 synonyms in the taxonomic literature (Hunziker, 1982). The three accessions representative of this traditional species do not form a monophyletic group on any of the gene trees (though a clade is not contradicted by waxy). One possible explanation is that there has been incomplete lineage sorting within the A clade. This seems unlikely because our screen of clones revealed no allele sharing among other species in the A clade: all alleles from a given group A species formed a clade at all loci. Another interpretation is that A. arborescens refers to a lowland progenitor form that has given rise to multiple novel higher-elevation forms, similar to the case of Lisianthus skinneri (Sytsma and Schaal, 1985). Alternatively, because A. arborescens may occasionally hybridize in nature with related higher-elevation taxa such as Iochroma confertiflorum (S. D. Smith, personal observation), it is possible that different $A$. arborescens populations have acquired different introgressed alleles from other members of the A clade.
Dunalia-Hunziker's (1960) delimitation of Dunalia centered on a single character, the presence of enlarged and showy "stapets," which appear as winged or toothed lateral appendages emerging from the filament bases at the point of their insertion on the corolla tube. Our analyses suggest that Dunalia sensu Hunziker (1960) is not monophyletic. Notably, the type species, $D$. solanacea appears more closely related to Saracha than to other Dunalia species. Whereas other Dunalia species are xerophytes of the central and southern Andes, $D$. solanacea is a northern Andean cloud forest shrub with a dense indumentum of stellate hairs, anisogeminate leaves, and small, yellow-green, trumpet-shaped flowers. Although its placement within Saracha could be a phylogenetic artifact (note that $D$. solanacea has a long terminal branch for all genes), there is no evidence of an association between this species and the other "Dunalia" species.

The remaining four Dunalia species are similar to each other in morphology, distribution, and habit; however, they do not form a clade in any of the trees. Furthermore, one species traditionally placed in Iochroma, I. parvifolium, appears more closely related to some dunalias. However, the association of $I$. parvifolium with $D$. brachyacantha and $D$. spinosa is reasonable given its spiny xerophytic habit and tubular purple flowers. Iochroma parvifolium was placed in Iochroma as opposed to Dunalia because it lacks the showy stapets (Hunziker, 1977). Nevertheless, close examination of fresh flowers of I. parvifolium in the field revealed small, tooth-like expansions of the stapets, which are hard to detect in dried specimens (S. D. Smith, personal observation). Also, during the course of collection trips, one population of I. parvifolium was found to be gynodioecious, a condition found in some Dunalia species (S. D. Smith, personal observation). Iochroma species (members of $\mathrm{A}, \mathrm{C}, \mathrm{L}, \mathrm{F}$, and $\mathrm{U}$ ) are invariably hermaphroditic and never spiny, making I. parvifolium an unlikely Iochroma. The epithet "parvifolia" does not exist in Dunalia, but transferring $I$. parvifolium to Dunalia is confounded by the fact that $D$. solanacea, the type species, is not associated with the other "Dunalia" species, making the taxonomic future of Dunalia uncertain. 

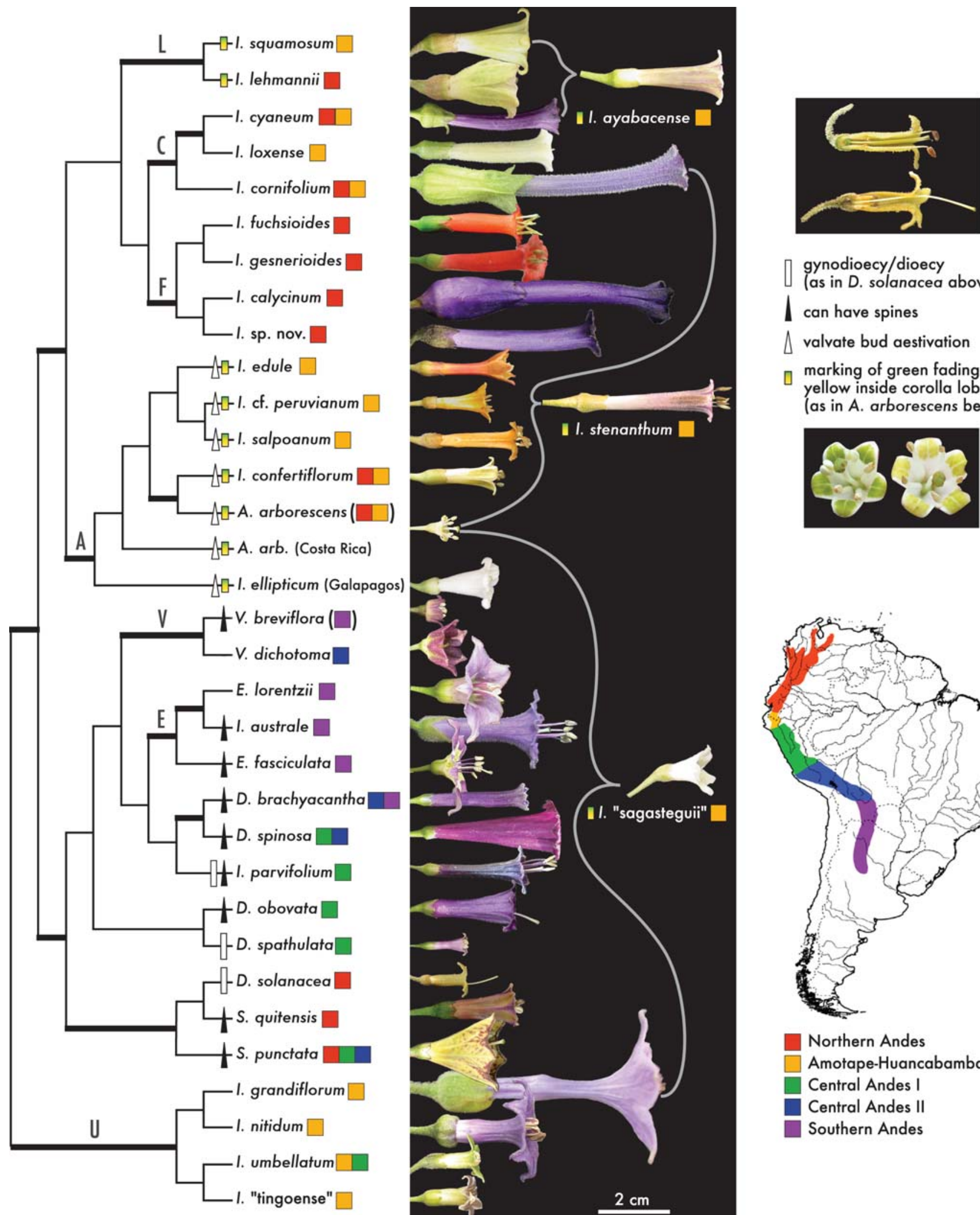

gynodioecy/dioecy (as in D. solanacea above)

\can have spines

$\triangle$ valvate bud aestivation

marking of green fading to

yellow inside corolla lobes (as in A. arborescens below)

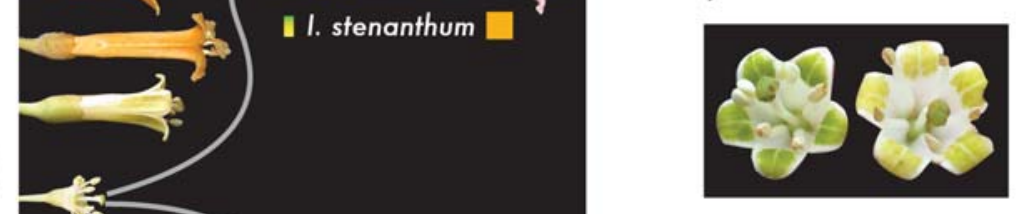

\section{os)}

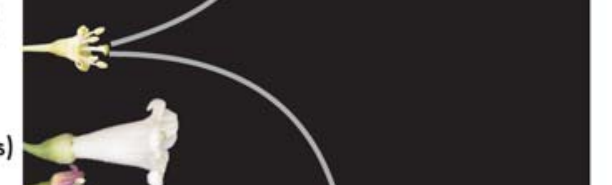

I. stenanthum
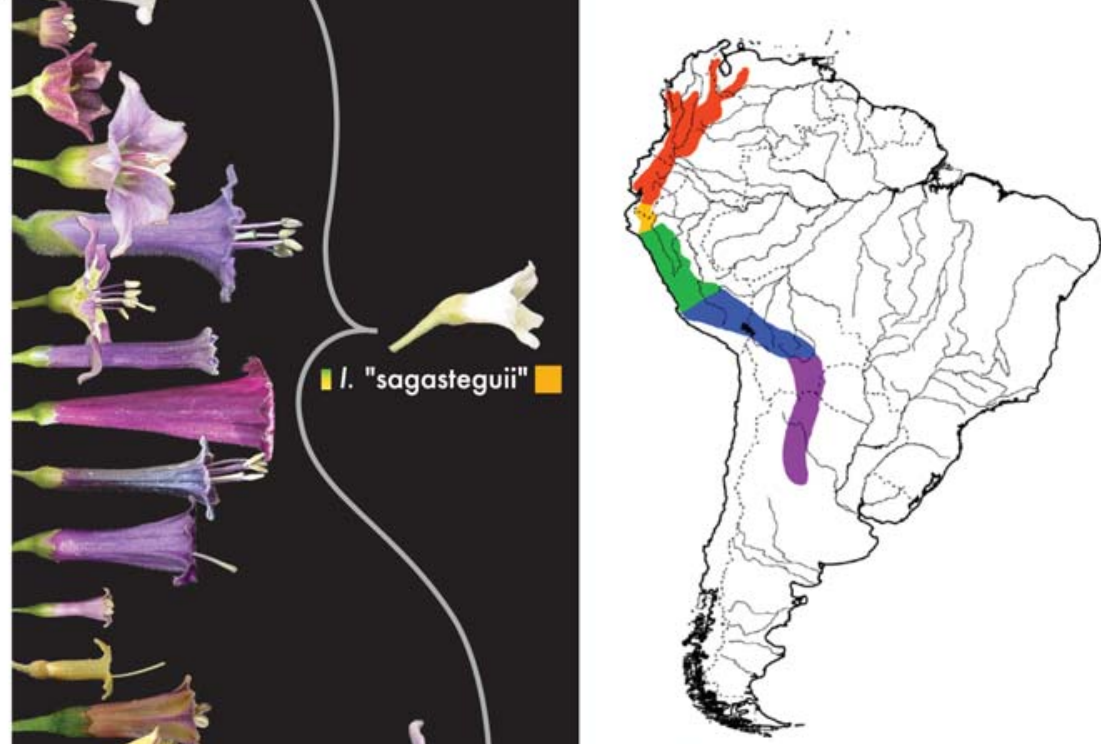

Northern Andes

Amotape-Huancabamba Zone

Central Andes I

Central Andes II

Southern Andes

Revised Fig. 3. Floral diversity, biogeography, and hybridization in Iochrominae. Cladogram showing relationships from combined analysis with the well-supported (BS > 70\%, PP > 0.95) branches bolded. See Fig. 2 caption for explanation of clade names (L, C, F, etc.); members of Dunalia and Saracha are not labeled as the genera are non-monophyletic. Colored boxes indicate entire geographic distribution with the exception of A. arborescens (widespread, with samples from Ecuador, Peru, and Costa Rica included in this analysis) and V. breviflora, (widespread through southern South America). 
Eriolarynx-The three species of Eriolarynx, recently segregated from Vassobia, can be distinguished from other Iochrominae by the dense ring of trichomes inside the corolla (Hunziker, 2000). Our analysis upholds the monophyly of Eriolarynx, with the addition of I. australe. This species was originally described in Iochroma (Grisebach, 1874), but later transferred to Acnistus (Grisebach, 1879) and then to Dunalia (Sleumer, 1950). Iochroma australe was not a good fit in Iochroma because its variable flowers can sometimes be short and funnel-shaped and because the corolla interior is densely pubescent near the base, whereas other Iochromas are typically glabrous. Further, it lacks the valvate aestivation of Acnistus and the characteristic filament appendages of Dunalia. The hairy flowers suggest a better fit with Eriolarynx despite the fact that the three described species typically have rotate or campanulate flowers, while I. australe has a funnel-shaped or tubular corolla. Geography also argues for this placement because both I. australe and Eriolarnyx are restricted to Bolivia and Argentina. There is no good argument against creating the new combination E. australe, except that this may prove to be only a temporary solution if it becomes necessary to combine the entire DESV clade into a single genus (with or without other elements of Iochrominae).

Iochroma-Species currently identified as Iochroma were not found to form a clade, even after the misplaced I. australe and I. parvifolium are ignored. One group of iochromas, the $\mathrm{U}$ clade appears as sister to remainder of Iochrominae. We consider this "U-sister" position to be strongly supported by our study for three reasons. First, two of the three loci sampled, ITS and $L F Y$, support or are compatible with the "U-sister" topology. Second, heuristic searches using the waxy data constrained to be consistent with "U-sister" topology do not result in trees that are significantly longer than unconstrained trees (Table 4). Last, despite the differences in topology among loci, support for a "U-sister" relationship is highest in the combined analysis. Specifically the combined analysis of all three genes yielded a $90 \%$ bootstrap, as contrasted with a $78 \%$ bootstrap support for this relationship in a two-gene combined analysis of $L F Y$ and ITS (not shown). This pattern suggests that even though waxy does not return $U$ as sister to the rest of Iochrominae, the waxy data do contain some support for this topology (Olmstead and Sweere, 1994).

The $U$ group is distinguished from species in the ACLF clade by the form of the corolla and the androecium. Flowers of ACLF (excluding Acnistus) are funnel-shaped or tubular, whereas those of the $U$ group are salverform. Also, the filaments are attached near the base in ACLF, while in the U group they are attached near the middle of the corolla tube (often with a visible bump at the point of attachment, e.g., I. grandiflorum, Fig 3.). The most extreme example of filament adnation in the U group is $I$. "tingoense" in which the anthers are more or less sessile on the corolla. Thus, even if one doubted the sister group relation between the $U$ clade and other Iochrominae, there is reason to believe that the $U$ clade is divergent from other traditional iochromas.
If the U clade (and I. australe and I. parvifolium) were excluded from Iochroma and if Acnistus were expanded to include the entire A clade (discussed previously), then one could imagine assigning only members of clades $\mathrm{C}$, L, and F to Iochroma. However, this decision would be premature considering that it is not certain from these data that $\mathrm{C}, \mathrm{L}$, and $\mathrm{F}$ form a clade. Furthermore, there are no clear morphological differences between Acnistus and Iochroma, largely because I. squamosum and I. lehmannii (clade L) possess a mixture of traits from clade $\mathrm{A}$ on the one hand and clades $\mathrm{C}$ and $\mathrm{F}$ on the other; the bud aestivation is induplicate, resulting in wide corolla lobes and plaits in the corolla tube, like $\mathrm{C}$ and $\mathrm{F}$, but the yellow flowers lack anthocyanins (Hunziker, 1982) and have the green markings on the corolla lobes, as in clade A. The other alternative, if we are to only recognize monophyletic groups, is to sink Acnistus into Iochroma. We also note that in a rank-independent system of nomenclature, Acnistus could be defined as a monophyletic group within a monophyletic Iochroma.

Saracha-This small genus of high-elevation treelets is morphologically well defined, including two species of páramo treelets with small coriaceous or subcoriaceous leaves and funnel-shaped or campanulate flowers that can be purple or yellow with purple spots (Alvarez, 1996). Dunalia solanacea, which often appears nested within Saracha, does not share any obvious features with Saracha except for its high-elevation distribution and occurrence in the northern Andes. As noted, $D$. solanacea has a long terminal branch for all tree genes, raising the possibility that its placement within Saracha is an artifact. Moreover, although Saracha only appears monophyletic in ITS trees and not in $L F Y$ or waxy trees, we note the sister relationship of $S$. quitensis and $S$. punctata does appears in Bayesian analyses of $L F Y$ with PP 0.08 and in those of waxy with PP 0.33 (Appendix S1, see Supplemental Data accompanying the online version of this article). Thus, we consider it premature to conclude that Saracha is nonmonophyletic.

Vassobia-Among the genera of Iochrominae, Vassobia is the only one that appeared monophyletic in all analyses. Vassobia includes two southern Andean species with small, purple, campanulate, glabrous flowers: $V$. dichotoma a cloud forest tree restricted to Bolivia, and $V$. breviflora, a widespread spiny shrub (Hunziker, 1984, 2001). The stapets of Vassobia are expanded to form small "auricles" similar to the appendages found in Eriolarynx (Hunziker, 2001). Considering that species of Eriolarynx formerly belonged to Vassobia, one might have expected a sister relationship between the genera. These data neither support nor strongly contradict this inference.

Hybridization in Iochrominae-Identifying hybrid taxa is a challenge for phylogenetics because reticulation erodes the strictly tree-like process of evolution assumed by most phylogenetic methods (McDade, 1990). Nonetheless, even when species trees are reticulate, gene trees will be strictly divergent structures so long as the rate of intragenic

The samples of $A$. arborescens from Peru and Ecuador are condensed to a single line because they appear to be sister taxa in the combined analysis; the $A$. arborescens from Costa Rica is abbreviated "A. arb." Gray, curved lines connect the putative hybrids, I. ayabacense, I. stenanthum, and I. "sagasteguii" to their putative parents. This figure differs from the print journal: the branch and associated symbols for $V$. breviflora and for $V$. dichotoma have been interchanged to align with the correct flower images.

A formal erratum appears in the September issue. 
recombination is low relative to the rate at which lineage sorting occurs. Given that homoploid hybrid taxa potentially carry genetic contributions from one or both parents, we may observe divergent alleles on a single gene tree (with alleles associated with each parent) or disagreement among gene trees, with hybrid alleles appearing related to one parental lineage on one tree and to the other parent on a different gene tree. Thus, we can test hypotheses of hybrid ancestry by identifying divergent alleles or points of conflict among gene trees (Doyle, 1992; Maddison, 1997). In this study, our sampling included three taxa, Iochroma ayabacense, I. "sagasteguii," and I. stenanthum, which we had hypothesized to be of hybrid origin due to their distribution and morphology.

Iochroma ayabacense was hypothesized to be an interspecific hybrid between I. cyaneum and I. squamosum. Iochroma ayabacense occurs in at high elevations (2600-2700 $\mathrm{m}$ a.s.1.) around the city of Ayabaca in northern Peru, often in proximity to populations of its putative parents, I. squamosum and I. cyaneum. The infrequent I. squamosum favors mildly disturbed habitats like forest gaps or riparian areas, whereas the widespread $I$. cyaneum tolerates drier conditions and open habitats like roadsides and pastures. The two putative parents are, however, found occasionally in close proximity, for example, when a road passes through a patch of forest. Several morphological features pointed to the possibility that $I$. ayabacense was a hybrid between these two. It has peculiar yellowish-purple flowers intermediate between the yellow $I$. squamosum and the purple I. cyaneum, and it has yellow-green markings inside the corolla, which are signatures of clades A and L. Our phylogenetic analyses revealed divergent alleles of I. ayabacense in both waxy and $L F Y$ trees, and in each case, one I. ayabacense allele fell in clade $\mathrm{C}$ and one in clade L (Fig. $2)$. In ITS trees, I. ayabacense appeared to be sister to $I$. squamosum in the L clade (Fig. 2). Considering these gene trees together with its distribution and morphology, we conclude that $I$. ayabacense is a hybrid between $I$. cyaneum and I. squamosum. Further field research and genetic data would be needed to determine if $I$. ayabacense is best interpreted as a hybrid species or a transient hybrid form that lacks sufficient permanence to warrant species status.

Iochroma "sagasteguii" has small white flowers with greenish markings inside the corolla that resemble Acnistus. However, the pubescence on the calyx and corolla, the slightly induplicate bud aestivation, and the extended area of filament adnation are reminiscent of species in the $\mathrm{U}$ group. Although the distribution of $I$. "sagasteguii" is not well known, in some localities in northern Peru, it grows within a few kilometers of populations of I. stenanthum, I. cornifolium, I. grandiflorum, and $I$. cf. peruvianum and within $15 \mathrm{~km}$ of populations of Acnistus arborescens. Similar to I. ayabacense, genetic evidence supported the hypothesis of hybrid ancestry in I. "sagasteguii." We found divergent alleles in the waxy tree, with one allele in the $\mathrm{U}$ group and another in clade $\mathrm{A}$. The genetic data, the morphology, and the geography point to I. grandiflorum and A. arborescens as the most likely parental species.

Iochroma stenanthum was the third suspected hybrid. It occurs in northern Peru and has long, tubular, pubescent flowers, most similar to I. cornifolium (Leiva et al., 1998), but with more triangular corolla lobes and yellow-green markings inside the corolla lobes as in clade A. The corolla color, which fades from cream at the base to purple at the apex, suggests that it is the result of crossing a white-flowered species (e.g., Acnistus arborescens) and a purple-flowered species. Iochroma sten- anthum occurs in close proximity of populations of the putative parents, I. cornifolium and A. arborescens. However, our data were insufficient to resolve the relationship of I. stenanthum to other Iochrominae. Its position varied among gene trees and was generally poorly supported. This pattern might be ascribed to lineage sorting, but its morphology is so strongly indicative of a hybrid ancestry that we favor the hypothesis that I. stenanthum is the product of a more ancient hybridization event whose genetic signatures have been blurred by subsequent evolution.

Biogeographical context of the Iochrominae radiationSimpson (1975) recognized that phytogeographical distributions in the Andes tend to coincide with the geologically defined structural units of the Cordilleras. Many subsequent authors have observed such a relationship (e.g., Berry, 1982; Luteyn, 2002), although the exact delimitation of the structural units and associated phytogeographic zones varies slightly among studies. For instance, Berry (1982) modified Simpson's (1975) structural units by recognizing the Amotape-Huancabamba zone $(\mathrm{A}-\mathrm{H}$ zone), an area of low elevation between the northern and central Andes $\left(4-8^{\circ} \mathrm{S}\right)$, as a separate unit. Weigend (2002; Weigend et al., 2004) supported Berry's distinction, noting the large number of A-H zone endemics, and additionally suggested distinguishing the Andes below $18^{\circ} \mathrm{S}$ as the southern Andes (as in Fig. 3). As a basis for discussing the biogeography of Iochrominae, it is useful to divide the tropical Andes into northern, central, and southern regions, to recognize the $\mathrm{A}-\mathrm{H}$ zone as a distinct unit, and to divide the central Andes into a region north of the Pisco deflection ( $14^{\circ} \mathrm{S}$; Berry's Cordillera Central and Occidental) and a region south of the deflection (Berry's Cordillera Oriental).

Similar to other plant groups that have radiated in the Andes (e.g., Fuchsia and Nasa), distribution patterns of Iochrominae species and clades strongly reflect the structural units of the Andes (Fig. 3). The diverse ACLF clade, excluding the weedy Acnistus arborescens and the Galapagos endemic Iochroma ellipticum, is restricted to the Andes from $5^{\circ} \mathrm{N}$ to $8^{\circ} \mathrm{S}$, the southern boundary of the A-H zone. The DEV group contains taxa that only occur below $8^{\circ} \mathrm{S}$, while its probable sister group, clade $\mathrm{S}$, is widely distributed from $9^{\circ} \mathrm{N}$ to $16^{\circ} \mathrm{S}$. Clade $\mathrm{U}$ straddles the ACLF and the DEV groups, with a distribution from $4^{\circ} \mathrm{S}$ (the northern limit of $\mathrm{A}-\mathrm{H}$ zone) to $10^{\circ} \mathrm{S}$.

Despite the clear patterns along the latitudinal gradient, we do not observe strong east-west separation of clades as has been the case in many Andean groups (Berry, 1982; Slade and Moritz, 1998; Brower, 1994). Although there is some tendency for greater species richness on the western cordilleras, several taxa, e.g., I. calycinum and Dunalia solanacea, are known to occur on both sides of the Andes. However, the distribution of many species remains poorly characterized. With increased collecting effort, it may eventually be possible to determine if Iochrominae distributions follow east-west structural units as closely as they do north-south units.

Iochrominae show a center of diversity in the A-H zone, where 16 of $33(48 \%)$ species (excluding I. cardenasianum) occur, 11 of which are restricted to this zone. This enhanced diversity can be attributed to the overlap of the ACLF and U clades. The A-H zone is characterized by fragments of the Cordilleras, usually less than $3500 \mathrm{~m}$ a.s.1, separated by valleys that dip down to ca. $1000 \mathrm{~m}$ a.s.l. Iochrominae prefer cloud forest or Andean scrub forest between 2300 and $2800 \mathrm{~m}$ a.s.l and are abundant in the high elevation valleys of the A-H zone. In some areas, as many as five species may occur over the distance of a few kilometers. The proximity coupled with the ease of 
crossing has resulted in several hybrid taxa, as revealed by this study, all of which are confined to this A-H zone (Fig. 3).

Here we have examined the three putative hybrid taxa with three loci, but this represents only a first attempt at exploring hybridization in Iochrominae. Further investigation into the potential hybrid ancestry of all Iochrominae should include samples of multiple individuals and populations per taxon, additional chromosome counts, statistical morphometric studies, characterization of species distributions, and analysis of mitochondrial or plastid markers. Greater sampling of individuals, taxa, and genes will permit a more fine-tuned estimate of the frequency of hybridization and introgression in Iochrominae history.

As documented in this study, episodes of hybridization have clearly impacted the evolutionary history of Iochrominae. However, considering the amount of agreement among the three nuclear markers, it appears that these events have not entirely obscured the underlying divergent phylogenetic history, having only clouded the branching pattern in some parts of the tree. Furthermore, the presence of leaky species boundaries has not apparently precluded the diversification of Iochrominae. In addition to being the most florally diverse subtribe in Physaleae and perhaps Solanoideae, Iochrominae also boasts the greatest diversity of pollination systems (Cocucci, 1999). Perhaps the combination of pollinatormediated selection, microallopatry in dissected Andean habitats and episodic hybridization have together permitted the explosion of floral diversity seen in Iochrominae.

\section{LITERATURE CITED}

Alvarez, A. 1996. Systematics of Saracha (Solanaceae). Master's thesis, University of Missouri-St. Louis, St. Louis, Missouri, USA.

Andreasen, K., B. G. Baldwin, and B. Bremer. 1999. Phylogenetic utility of the nuclear rDNA ITS region in subfamily Ixoroideae (Rubiaceae): comparisons with cpDNA rbcL sequence data. Plant Systematics and Evolution 217: 119-135

BAtes, J. M., AND R. M. ZiNK. 1994. Evolution into the Andes: molecular evidence for species relationships in the genus Leptopogon. Auk 111: $507-515$

Baum, D. A., R. L. Small, and J. F. Wendel. 1998. Biogeography and floral evolution of baobabs (Adansonia, Bombacaceae) as inferred from multiple data sets. Systematic Biology 47: 181-207.

Baum, D. A., K. J. Sytsma, And P. C. Носн. 1994. A phylogenetic analysis of Epilobium (Onagraceae) based on nuclear ribosomal DNA sequences. Systematic Botany 19: 363-388.

BerRy, P. E. 1982. The systematics and evolution of Fuchsia sect. Fuchsia (Onagraceae). Annals of the Missouri Botanical Garden 69: 1-198.

Bleiweiss, R. 1998. Origin of hummingbird faunas. Biological Journal of the Linnean Society 65: 77-97.

BROWER, A. V. Z. 1994. Rapid morphological radiation and convergence among races of the butterfly Heliconius erato inferred from patterns of mitochondrial DNA evolution. Proceedings of the National Academy of Sciences, USA 91: 6491-6495.

Buckley, T. R., P. Arensburger, C. Simon, and G. K. Chambers. 2002. Combined data, Bayesian phylogenetics, and the origin of the New Zealand cicada genera. Systematic Biology 51: 4-18.

Catalán, P., E. A. Kellogg, and R. G. Olmstead. 1997. Phylogeny of Poaceae subfamily Pooideae based on chloroplast $n d h F$ gene sequencing. Molecular Phylogenetics and Evolution 8: 150-166.

Chase, M. W., And H. H. Hills. 1991. Silica gel: an ideal material for field preservation of leaf samples for DNA studies. Taxon 40: 215-220.

CocucCI, A. 1999. Evolutionary radiation in Neotropical Solanaceae. In M. Nee, D. E. Symon, R. N. Lester, and J. P. Jessop [eds.], Solanaceae IV: advances in biology and utilization, 9-22. Royal Botanic Gardens, Kew, UK.
D'Arcy, W. G. 1991. The Solanaceae since 1976, with a review of its biogeography. In J. G. Hawkes, R. N. Lester, M. Nee, and N. EstradaR [eds.], Solanaceae III: taxonomy, chemistry and evolution, 75-137. Royal Botanic Gardens, Kew, UK.

Darlu, P., AND G. LeCointre. 2002. When does the incongruence length difference test fail? Molecular Biology and Evolution 19: 432-437.

Doyle, J. J. 1992. Gene trees and species trees: molecular systematics as one-character taxonomy. Systematic Botany 17: 144-163.

Doyle, J. J., AND J. L. Doyle. 1987. A rapid DNA isolation procedure from small quantities of fresh leaf tissues. Phytochemical Bulletin 19: 11-15.

Dressler, R. L. 1981. The orchids: natural history and classification. Harvard University Press, Cambridge, Massachusetts, USA.

Farris, J. S., M. Källersjö, A. G. Kluge, and C. Bult. 1994. Testing significance of incongruence. Cladistics 10: 315-319.

Gentry, A. H. 1982. Neotropical floristic diversity: phytogeographical connections between Central and South America, Pleistocene climatic fluctuations, or an accident of the Andean orogeny? Annals of the Missouri Botanical Garden 69: 557-593.

Grisebach, A. 1874. Plantae Lorentzianae. Abhandlungen der Königlichen Gesellschaft der Wissenschaften zu Göttingen 19: 49-279.

GrisebaCH, A. 1879. Symbolae ad floram Argentinam. Abhandlungen der Königlichen Gesellschaft der Wissenschaften zu Göttingen 24: 3-345.

Hamby, R. K., AND E. A. Zimmer. 1992. Ribosomal RNA as a phylogenetic tool in plant systematics. In P. S. Soltis, D. E. Soltis, and J. J. Doyle [eds.], Molecular systematics of plants, 50-91. Chapman and Hall, New York, New York, USA.

Hillis, D. M., AND J. P. HuelsenBeCK. 1992. Signal, noise and reliability in molecular phylogenetic analyses. Journal of Heredity 83: 189-195.

Hipp, A. L., J. C. Hall, and K. J. Sytsma. 2004. Congruence versus phylogenetic accuracy: revisiting the incongruence length difference test. Systematic Biology 53: 81-89.

Hooghiemstra, H., and T. Van Der Hammen. 1998. Neogene and quaternary development of the Neotropical rain forest: the forest refugia hypothesis, and a literature overview. Earth Science Reviews 44: 147-183.

Hooghiemstra, H., T. Van Der Hammen, and A. M. Cleef. 2002. Paleoecología de la flora boscosa. In M. R. Guariguata and G. H. Kattan [eds.], Ecología y conservación de bosques neotropicales, 4358. Editorial Libro Universitario Regional, Cartago, Costa Rica.

Hoorn, C., J. Guerrero, G. A. Sarmiento, and M. A. Lorente. 1995. Andean tectonics as a cause for changing drainage patterns in Miocene northern South America. Geology 23: 237-240.

Howarth, D. G., AND D. A. Baum. 2005. Genealogical evidence of homoploid hybrid speciation in an adaptive radiation of Scaevola (Goodeniaceae) in the Hawaiian Islands. Evolution 59: 948-961.

Huelsenbeck, J. P., B. Larget, R. E. Miller, and F. Ronquist. 2002. Potential applications and pitfalls of Bayesian inference of phylogeny. Systematic Biology 51: 673-688.

HunZIKER, A. T. 1960. Estudios sobre Solanaceae II. Sinopsis taxonómica del género Dunalia H. B. K. Boletín de la Academia Nacional de Ciencias 51: 211-244.

HunZIKER, A. T. 1977. Estudios sobre Solanaceae VIII. Part IV. Sobre dos nuevas secciones de Iochroma y dos novedades a nivel específico. Kurtziana 10: 21-25.

HunZIKER, A. T. 1982. Estudios sobre Solanaceae XVII. Revisión sinóptica de Acnistus. Kurtziana 15: 81-102.

HunZIKER, A. T. 1984. Estudios sobre Solanaceae XIX. Sinopsis de Vassobia. Kurtziana 17: 91-118.

HunziKer, A. T. 2000. Two novelties for the tribe Solaneae (Solanaceae). Kurtziana 28: 65-68.

HunZiKer, A. T. 2001. Genera of Solanaceae. A. R. G. Ganter Verlag K. G., Konigstein, Germany.

Kay, K. M., P. A. Reeves, R. G. Olmstead, and D. W. Schemske. 2005. Rapid speciation and the evolution of hummingbird pollination in neotropical Costus subgenus Costus (Costaceae): evidence from nrDNA ITS and ETS sequences. American Journal of Botany 92: 1899-1910.

LARSON, A. 1994. The comparison of morphological and molecular data in phylogenetic systematics. In B. Schierwater, B. Streit, G. P. Wagner, 
and R. DeSalle [eds.], Molecular ecology and evolution: applications and approaches, 371-390. Birkhauser Verlag, Basel, Switzerland.

LeIva G., S. 1995. Una nueva especie de Iochroma (Solanaceae: Solaneae) del norte del Perú. Arnaldoa 3: 41-44.

Leiva G., S., V. S. QuipusCoA, AND N. W. SAwyer. 1998. Iochroma stenanthum (Solanaceae: Solaneae), una nueva especie del norte de Perú. Arnaldoa 5: 77-82.

Leiva G., S., P. A. Lezama, and V. S. Quipuscoa. 2003. Iochroma salpoanum y I. squamosum (Solanaceae: Solaneae), dos nuevas especies andinas del norte del Perú. Arnaldoa 10: 95-104.

Luteyn, J. L. 2002. Diversity, adaptation and endemism in Neotropical Ericaceae: biogeographical patterns in the Vaccinieae. Botanical Review 68: 55-87.

Maddison, D. R., AND W. P. Maddison. 2000. MacClade 4: analysis of phylogeny and character evolution. Sinauer, Sunderland, Massachusetts, USA.

Maddison, W. P. 1997. Gene trees in species trees. Systematic Biology 46: 523-536.

Marshall, J. A., S. Knapp, M. R. Davey, J. B. Power, E. C. Cocking, M. D. Bennett, And A. V. Cox. 2001. Molecular systematics of Solanum section Lycopersicum (Lycopersicon) using nuclear ITS rDNA region. Theoretical and Applied Genetics 103: 1216-1222.

Martin, D., AND E. RYbicki. 2000. RDP: detection of recombination amongst aligned sequences. Bioinformatics 16: 562-563.

Martins, T. R., AND T. J. BARKMAN. 2005. Reconstruction of Solanaceae phylogeny using the nuclear gene SAMT. Systematic Botany 30: 435-447.

Mason-Gamer, R. J., and E. A. Kellogg. 1996. Testing for phylogenetic conflict among molecular data sets in the tribe Triticeae. Systematic Biology 45: 524-545.

Maynard Smith, J. 1992. Analyzing the mosaic structure of genes. Journal of Molecular Evolution 34: 126-129.

McDAde, L. 1990. Hybrids and phylogenetic systematics I. Patterns of character expression in hybrids and their implications for cladistic analysis. Evolution 44: 1685-1700.

Myers, N., R. A. Mittermeier, C. G. Mittermeier, G. A. B. Da Fonseca, AND J. KENT. 2000. Biodiversity hotspots for conservation priorities. Nature 403: 853-858.

Оh, S. H., AND D. Potter. 2003. Phylogenetic utility of the second intron of LEAFY in Neillia and Stephanandra (Rosaceae) and implications for the origin of Stephanandra. Molecular Phylogenetics and Evolution 29: 203-215.

Olmstead, R. G., AND J. A. Sweere. 1994. Combining data in phylogenetic systematics: an empirical approach using three molecular data sets in the Solanaceae. Systematic Biology 43: 467-481.

Olmstead, R.G., J. A. Sweere, R. E. Spangler, L. Bohs, and J. D. Palmer. 1999. Phylogeny and provisional classification of the Solanaceae based on chloroplast DNA. In M. Nee, D. E. Symon, R. N. Lester, and J. P. Jessop [eds.], Solanaceae IV: advances in biology and utilization, 111-137. Royal Botanic Gardens, Kew, UK.

Padidam, M., S. SAwYer, AND C. M. FAuQuet. 1999. Possible emergence of new geminiviruses by frequent recombination. Virology 265: 218-225.

Patton, J. L., AND M. F. Smith. 1992. mtDNA phylogeny of Andean mice: a test of diversification across ecological gradients. Evolution 46: $174-183$.

Peralta, I. E., And D. M. Spooner. 2001. Granule-bound starch synthase
(GBSSI) gene phylogeny of wild tomatoes (Solanum L. section Lycopersicon [Mill.] Wettst. subsection Lycopersicon). American Journal of Botany 88: 1888-1902.

PosADA, D. 2002. Evaluation of methods for detecting recombination from DNA sequences: empirical data. Molecular Biology and Evolution 19: 708-717.

Posada, D., and K. A. Crandall. 2001 Performance of methods for detecting recombination from DNA sequences: computer simulations. Proceedings of the National Academy of Sciences, USA 98: 1375713762.

Ronquist, F., AND J. P. HuelsenbeCK. 2003. MRBAYES 3: Bayesian phylogenetic inference under mixed models. Bioinformatics 19: 1572-1574

SAwYeR, N. W. 2005. Systematics of Deprea and Larnax (Solanaceae) based on morphological evidence. In R. C. Keating, V. C. Hollowell, and T. B. Croat [eds.], A festschrift for William G. D'Arcy, 259-285. Missouri Botanical Garden, St. Louis, Missouri, USA.

Shaw, J. M. H. 1998. Iochroma: a review. New Plantsman 5: 154-191.

Simpson, B. B. 1975. Pleistocene changes in the flora of the high tropical Andes. Paleobiology 1: 273-294.

Slade, R. W., and C. Moritz. 1998. Phylogeography of Bufo marinus from its natural and introduced ranges. Proceedings of the Royal Society of London, B, Biological Sciences 265: 769-777.

Sleumer, H. 1950. Estudios sobre el género Dunalia H. B. K. Lilloa 23 : $117-142$

SwOFFORD, D. L. 2002. PAUP*: phylogenetic analysis using parsimony (*and other methods), version 4.0b10. Sinauer, Sunderland, Massachusetts, USA

Swofford, D. L., G. J. Olsen, P. J. Waddell, and D. M. Hillis. 1996. Phylogenetic inference. In D. M. Hillis, C. Moritz, and B. K. Mable [eds.], Molecular systematics, 407-514. Sinauer, Sunderland, Massachusetts, USA.

Systma, K. J., And B. A. SchaAl. 1985. Phylogenetics of the Lisanthus skinneri (Gentianaceae) species complex in Panama utilizing DNA restriction fragment analysis. Evolution 39: 594-608.

Templeton, A. R. 1983. Phylogenetic inference from restriction endonuclease cleavage site maps with particular reference to the humans and apes. Evolution 37: 221-244.

Von Hagen, K. B., and J. W. Kadereit. 2003. The diversification of Halenia (Gentianaceae): ecological opportunity versus key innovation. Evolution 57: 2507-2518.

WeIGEND, M. 2002. Observations on the biogeography of the AmotapeHuancabamba zone in northern Peru. Botanical Review 68: 38-54.

Weigend, M., M. Gottschling, S. Hoot, And M. Ackermann. 2004. A preliminary phylogeny of Loasaceae subfam. Loasoideae (Angiospermae: Cornales) based on $\operatorname{trn} \mathrm{L}_{(\mathrm{UAA})}$ sequence data, with consequences for systematics and historical biogeography. Organisms, Diversity and Evolution 4: 73-90.

White, T. J., T. Bruns, S. LeE, AND J. W. TAYlor. 1990. Amplification and direct sequencing of fungal ribosomal RNA genes for phylogenetics. In M. A. Innis, D. H. Gelfand, J. J. Sninsky, and T. J. White [eds.], PCR protocols: a guide to methods and applications, 315-322. Academic Press, New York, New York, USA.

Whitson, M., And P. S. Manos. 2005. Untangling Physalis (Solanaceae) from the Physaloids: a two-gene phylogeny of Physalinae. Systematic Botany 30: 216-230.

APPENDIX 1. Taxon sampling within Solanoideae, GenBank accession numbers (ITS, LFY, waxy), and voucher information. Tribes (ending -eae) and subtribes (ending -inae) are given when available (Olmstead et al., 1999; R. G. Olmstead et al., University of Washington, personal communication). Voucher specimens have been deposited in the following herbaria: BIRM = University of Birmingham; CDS = Charles Darwin Research Station, NY $=$ New York Botanical Garden, UT = University of Utah, WIS = University of Wisconsin-Madison.

Tribe

Subtribe

Taxon-GenBank accession nos.: ITS, LFY, waxy; voucher information.

Nicandreae

Nicandra physaloides (L.) Gaertn.-DQ314155, DQ309515, DQ309465;

Peru. Dept. Amazonas. Prov. Chachapoyas, $6.24291^{\circ} \mathrm{S} 77.87443^{\circ} \mathrm{W}$ 2250 m, 11-II-04, Smith 369, WIS. 


\section{Datureae}

Iochroma cardenasianum Hunz.-DQ314156, DQ309516, DQ309466; Bolivia. Dept. Potosí. Carretera Potosi-Orkhola-Tumusla. 20.39638 ${ }^{\circ} \mathrm{S}$ 65.56287º W, 3099 m, 18-II-04, Smith 385, WIS.

\section{Solaneae}

Solanum lycopersicum L.-DQ314157, DQ309517, DQ309467; UWMadison, Botany Living Collections s.n.

Capsiceae

Capsicum lycianthoides Bitter-DQ314158, DQ309518, DQ309468; Ecuador. Prov. Pichincha. $0.0157^{\circ} \mathrm{S} 78.680^{\circ} \mathrm{W}, 2250 \mathrm{~m}, 23-\mathrm{XII}-02$, Smith 203, WIS.

Lycianthes inaequilatera Bitter-DQ314159, DQ309519, DQ309469; Ecuador. Prov. Pichincha. $0.326^{\circ} \mathrm{S} 79.000^{\circ} \mathrm{W} 800 \mathrm{~m}, 25-\mathrm{XII}-02$, Smith 210, WIS.

Physaleae

Salpichroinae

Salpichroa tristis Walp.-DQ314160, DQ309520, DQ309470; Bolivia. Dept. Potosí. Ca. $19.5^{\circ} \mathrm{S} 65.45^{\circ} \mathrm{W}, 4020$ m, 18-II-04, Smith 382, WIS.

Physalinae

Physalis peruviana L.-DQ314161, DQ301514, DQ309471; Ecuador. Prov. Pichincha. Gardens of Herbario Nacional (QCNE), 2800 m, 1-I03, Smith 217, WIS.

Leucophysalis grandiflora (Hook.) Rydb.-DQ314162, DQ301515, DQ309472; Olmstead S-30, WTU.

Witheringia solanacea L'Herit.-DQ314164, DQ301517, DQ309474; D'Arcy 16399, MO.

Withaninae

Tubocapsicum anomalum (Franchet \& Savat.) Makino-DQ314163, DQ301516, DQ309473; Chen 231, MO.

[Subtribe not known]

Cuatresia harlingiana Hunz.-DQ314165, DQ301518, DQ309475; Ecuador. Prov. Pichincha. $0.0157^{\circ} \mathrm{S} 78.680^{\circ} \mathrm{W}, 2250 \mathrm{~m}, 24-X I I-02$, Smith 204, WIS.

Larnax sachapapa Hunz.-DQ314166, DQ301519, DQ309476; Ecuador. Prov. Pichincha. $0.0157^{\circ} \mathrm{S} 78.680^{\circ} \mathrm{W}, 2250 \mathrm{~m}, 24-\mathrm{XII}-02$, Smith 205, WIS.

Iochrominae

Acnistus arborescens (L.) Schlecht.-DQ314173, DQ301528, DQ309483; Costa Rica. Prov. Puntarenas. Las Cruces B. S., 1992, Bohs 2428, UT. A. arborescens (L.) Schlecht.-DQ314181, DQ301536, DQ309491; Ecuador. Prov. Pichincha. 0.3260'S 79. $000^{\circ} \mathrm{W}, 750 \mathrm{~m}, 25-\mathrm{XII}-02$, Smith 209, WIS. A. arborescens (L.) Schlecht._DQ314183, DQ301538, DQ309493; Peru. Dept. Cajamarca. $7.42409^{\circ} \mathrm{W} 78.90111^{\circ} \mathrm{S}, 1976 \mathrm{~m}, 10-\mathrm{I}-04$, Smith 312, WIS.

Dunalia brachyacantha Miers-DQ314172, DQ301527, DQ309482; Argentina. Prov. Jujuy, $2100 \mathrm{~m}, 20-\mathrm{IX}-02$, Nee and Bohs 50811, NY. D. obovata Dammer-DQ314192, DQ301547, DQ309499; Peru. Dept. Junin. $11.34919^{\circ} \mathrm{S} 75.57408^{\circ} \mathrm{W}, 2679 \mathrm{~m}, 8-\mathrm{III}-04$, Smith 458, WIS. D. spathulata (Ruíz \& Pav.) Braun \& Aschers-DQ314198, DQ301554, DQ309506; Peru. Dept. Huanuco. 9.83831 ${ }^{\circ} \mathrm{S} 76$. $11503^{\circ} \mathrm{W}, 1842$ m, 6-III-04, Smith 452, WIS. D. solanacea H. B. \& K.-DQ314174, DQ301529, DQ309484; Ecuador. Dept. Pichincha, ca. $0.23^{\circ} \mathrm{S} 78.75^{\circ} \mathrm{W}$, ca. $2200 \mathrm{~m}, 31-\mathrm{XII}-02$, Smith 211, WIS. D. spinosa Dammer-DQ314188, DQ301543, DQ309495; Bolivia. Dept. Potosi, ca. $19.6^{\circ} \mathrm{S} 65.6^{\circ} \mathrm{W}, 4020 \mathrm{~m}, 18-\mathrm{II}-04$, Smith 379, WIS.

Eriolarynx lorentzii (Dammer) Hunz.-DQ314171, DQ301525/ DQ301526 (allele A/allele B); DQ309481; Argentina. Prov. Tucuman, $26.633^{\circ} \mathrm{S} 65.467^{\circ} \mathrm{W}, 1700 \mathrm{~m}, 12-\mathrm{II}-1966$, Hawkes et al. 3452, BIRM. E. fasciculata (Miers) Hunz.-DQ314196, DQ301552, DQ309504; Bolivia. Dept. Cochabamba, $17.46477^{\circ} \mathrm{S} 65.75217^{\circ} \mathrm{W}$, 3180 m, 26-II-04, Smith 432, WIS.

Iochroma australe Griseb.-DQ314189, DQ301544, DQ309496; Bolivia. Dept. Chuquisaca. $20.78477^{\circ} \mathrm{S} 65.04088^{\circ} \mathrm{W}, 3038 \mathrm{~m}, 18-\mathrm{II}-04$, Smith 390, WIS. I. ayabacense S. Leiva-DQ314194, DQ301549/DQ301550 (allele A/allele B), DQ309501/DQ309502 (allele A/allele B); Peru. Dept. Piura. $4.61462^{\circ} \mathrm{S} 79.71178^{\circ} \mathrm{W}, 2701$ $\mathrm{m}$, 15-I-04, Smith 337, WIS. I. calycinum Benth.-DQ314201, DQ301557, DQ309512; Ecuador. Prov. Pichincha. 0.24577 S 78. 80903 W, 1834 m, 27-XII-04, Smith 471, WIS. I. confertiflorum
(Miers) Hunz.-DQ314176, DQ301531, DQ309486; Ecuador. Prov. Loja, $4.1316^{\circ} \mathrm{S} 79.9218^{\circ} \mathrm{W}, 1582 \mathrm{~m}, 15-\mathrm{I}-03$, Smith 237, WIS. I. cornifolium Miers-DQ314177, DQ301532, DQ309487; Ecuador. Prov. Loja, $4.0869^{\circ} \mathrm{S} 79.9356^{\circ} \mathrm{W}, 2570 \mathrm{~m}, 15-\mathrm{I}-03$, Smith 242, WIS. I. cyaneum (Lindl.) M. L. Green-DQ314180, DQ301535, DQ309490; Ecuador. Prov. Loja, $3.849^{\circ} \mathrm{S} 79.427^{\circ} \mathrm{W}, 2325$ m, 4-I-03, Smith 223, WIS. I. edule Leiva-DQ314193, DQ301548, DQ309500; Peru. Dept. La Libertad, $7.928183^{\circ} \mathrm{S} 78.58368^{\circ} \mathrm{W}, 2550 \mathrm{~m}, 8-\mathrm{I}-04$, Smith 300, WIS. I. ellipticum (Hook. f.) Hunz.-DQ314199, DQ301555, DQ309507; Ecuador. Galapagos, $0.2203^{\circ} \mathrm{S} 90.7627^{\circ} \mathrm{W}, 700 \mathrm{~m}, 6-\mathrm{X}-02$, Jager 622, CDS. I. fuchsioides Miers-DQ314203, DQ301559, DQ309514; Ecuador. Prov. Azuay. 2.75117 ${ }^{\circ} \mathrm{S} 78.88629^{\circ} \mathrm{W}, 2828 \mathrm{~m}, 9-\mathrm{I}-05$, Smith 488, WIS. I. gesnerioides Miers-DQ314179, DQ301534, DQ309489; Ecuador. Prov. Pichincha, $00.0394^{\circ} \mathrm{N} 78.500^{\circ} \mathrm{W}, 2500 \mathrm{~m}$, 20-XII-02, Smith 200, WIS. I. grandiflorum Benth.-DQ314170, DQ301523, DQ309480; Peru. Prov. Cajamarca, $7.37908^{\circ} \mathrm{W} 78$. $89332^{\circ} \mathrm{S}, 2781 \mathrm{~m}, 11-\mathrm{I}-04$, Smith 320, WIS. I. lehmannii BitterDQ314200, DQ301556, DQ309511; Ecuador. Prov. Cañar, 2.31973 S 78.92679 W, 2475 m, 8-I-05, Smith 484, WIS. I. loxense MiersDQ314175, DQ301530, DQ309485; Ecuador. Prov. Loja, 3.999 79. $306^{\circ} \mathrm{W}, 2050 \mathrm{~m}, 3-\mathrm{I}-03$, Smith 220, WIS. I. nitidum S. Leiva \& Quipuscoa-DQ314168, DQ301521, DQ309478; Peru. Dept. Amazons, 6.38960 $77.98795^{\circ} \mathrm{W}, 2605$ m, 11-I-04, Smith 371, WIS. I. parvifolium (Roem. \& Schult.) D'Arcy-DQ314195, DQ301551, DQ309503; Peru. Dept. La Libertad, $7.9477167^{\circ} \mathrm{W} 78.56195^{\circ} \mathrm{S}, 2759$ m, 8-I-04, Smith 303, WIS. I. cf. peruvianum (Dunal) J. F. Macbr.DQ314197, DQ301553, DQ309505; Peru. Dept. Cajamarca, $7.38597^{\circ} \mathrm{S}$ $78.89774^{\circ} \mathrm{W}, 2602 \mathrm{~m}, 16-\mathrm{I}-04$, Smith 353, WIS. I. salpoanum S. Leiva \& Lezama-DQ314187, DQ301542, DQ309509; Peru. Dept. La Libertad. $8.00878^{\circ} \mathrm{S} 78.63911^{\circ} \mathrm{W}, 2696 \mathrm{~m}, 10-\mathrm{II}-04$, Smith 364, WIS. I. squamosum S. Leiva \& Quipuscoa-DQ314186, DQ301541, DQ309494; Peru. Dept. Piura. $4.659652^{\circ} \mathrm{S} 79.74038^{\circ} \mathrm{W}, 2730 \mathrm{~m}, 14$ I-04, Smith 330, WIS. I. stenanthum S. Leiva, Quipuscoa \& N. W. Sawyer-DQ314184, DQ301539, DQ309508; Peru. Dept. Cajamarca, $7.40116^{\circ} \mathrm{S} 78.89658^{\circ} \mathrm{W}, 1976 \mathrm{~m}, 10-\mathrm{I}-04$, Smith 313, WIS. I. sp. nov.-DQ314202, DQ301558, DQ309513; Ecuador. Prov. Napo, 0. $36794^{\circ} \mathrm{S} 78.10471^{\circ} \mathrm{W}, 2811 \mathrm{~m}, 4-\mathrm{I}-05$, Smith 476, WIS. I. sp. nov. "sagasteguii"_-DQ314185, DQ301524/DQ301540 (allele A/allele B), DQ309510; Peru. Dept. Cajamarca. $7.38489^{\circ} \mathrm{S} 78.89720^{\circ} \mathrm{W}, 2603 \mathrm{~m}$, 10-I-04, Smith 317, WIS. I. sp. nov. "tingoense"-DQ314167, DQ301520, DQ309477; Peru. Dept. Amazonas, 6.37972 ${ }^{\circ} \mathrm{S} 77$. $90962^{\circ} \mathrm{W}, 1800$ m, 11-I-04, Smith 370, WIS. I. umbellatum (Ruíz \& Pav.) D'Arcy — DQ314169, DQ301522, DQ309479; Peru. Dept. La Libertad, 7.9344167 ${ }^{\circ} \mathrm{S} 78.592367^{\circ} \mathrm{W}, 2468$ m, 8-I-04, Smith 301, WIS. Saracha punctata Ruíz \& Pav._- DQ314182, DQ301537, DQ309492; Bolivia. Dept. La Paz, $16.32694^{\circ} \mathrm{S} 67.89167^{\circ} \mathrm{W}, 2850 \mathrm{~m}, 12-\mathrm{V}-01$, Nee 51804, NY. S. quitensis (Hook.) Miers-DQ314178, DQ301533, DQ309488; Ecuador. Prov. Napo, $0.3824^{\circ} \mathrm{S} 78.1600^{\circ} \mathrm{W}, 3400 \mathrm{~m}, 21-\mathrm{I}-$ 03, Smith 257, WIS.

Vassobia breviflora (Sendt.) Hunz.-DQ314190, DQ301545, DQ309497; Bolivia. Dept. Chuquisaca, $18.89368^{\circ} \mathrm{S} 65.11555^{\circ} \mathrm{W}, 1922 \mathrm{~m}, 22-\mathrm{II}-$ 04, Smith 412, WIS. V. dichotoma (Rusby) Bitter-DQ314191, DQ301546, DQ309498; Bolivia. Dept. La Paz, 16.32033 S 67. $82700^{\circ} \mathrm{W}, 2157 \mathrm{~m}, 28-\mathrm{II}-04$, Smith 440, WIS.

ApPENDIX 2. PCR primers designed for this study. All primers listed $5^{\prime}$ to $3^{\prime}$.

\begin{tabular}{lll}
\hline \hline Locus & \multicolumn{1}{c}{ Primer } & \multicolumn{1}{c}{ Sequence } \\
\hline waxy & F41 & GGT GAT GTT CTT GCT GGA CTA C \\
waxy & F420 & CGT GGG GTT GAT CGT GTT TTT G \\
waxy & R991 & CCT TCG CAT TCA CAT AGA TTC C \\
waxy & R1235 & GCT TCT AAA CTT GGT GGT CTG A \\
$L F Y$ & LFYSOL-F7 & AAY GGY YTR GAT TAY YTG TTC CAT \\
$L F Y$ & LFYSOL-F68 & AGA MTA TTG CYA AGG AAC GRG GTG \\
$L F Y$ & LFYSOL-R700 & GAC AMT RTW GAR AAG TRC GTA GCA \\
$L F Y$ & LFYSOL-R1000 & CAA GGT TAC AGG TGG AGR TAC TYG \\
\hline
\end{tabular}

